\title{
A Kralodvorian (upper Katian, Upper Ordovician) benthic association from the Ferradosa Formation (Central Portugal) and its significance for the redefinition and subdivision of the Kralodvorian Stage
}

\author{
Jorge Colmenar, SOFia Pereira, Miguel Pires, CARlos MARQues dA Silva, \\ ARTUR ABREU SÁ \& TIMOTHY P. YOUNG
}

\begin{abstract}
A new upper Katian (Kralodvorian Regional Stage) benthic association from the Riba de Cima Member of the Ferradosa Formation, Portugal, is described. It is dominated by bryozoans and echinoderms but brachiopods and trilobites are also present. More than 20 species of brachiopods, nine of trilobites and eight of echinoderms have been identified in the four studied localities. Among the brachiopods Kjaerina (Villasina) meloui Colmenar, 2016, Dolerorthis abeirensis Mélou, 1990 and Bicuspina cf. armoricana Mélou, 1990 are significant. These species were previously recorded only in the uppermost Rosan Formation (Armorican Massif, France). Porambonites dreyfussi Havlíček, 1981 is also reported in this paper for the first time besides its type horizon in the upper part of the Kralodvorian Gabian Formation (Montagne Noire, France). Most of the identified trilobite taxa were previously documented only in the Kralodvorian Cystoid Limestone Formation (Iberian Chains, Spain), except Parillaenus? cf. creber Hammann, 1992 and Amphoriops cf. inflatus (Hammann, 1992), whose referred species are also present in the upper Berounian-Kralodvorian Portixeddu Formation in Sardinia. The record of "Ceraurinus" meridianus (Hammann, 1992), "Bumastus" aff. commodus Apollonov, 1980 and Amphoriops cf. inflatus represent the first occurrence of these genera-groups in Portugal. These records are important additions to the knowledge of the Portuguese Late Ordovician benthic marine communities, providing crucial new data to constrain the biostratigraphy of the Riba de Cima Member and the palaeogeographical setting of this region at that time. In addition, some of the brachiopod occurrences with more restricted stratigraphical ranges provide invaluable tools for enabling more precise subdivision of the Kralodvorian regional stage. $\bullet$ Key words: South Gondwana, Riba de Cima Member, Buçaco Syncline, upper Katian, Nicolella Fauna.
\end{abstract}

Jorge Colmenar, Sofia Pereira, Miguel Pires, Carlos Marques da Silva, Artur Abreu SÁ \& Timothy P. Young 2017. A Kralodvorian (upper Katian, Upper Ordovician) benthic association from the Ferradosa Formation (central Portugal) and its significance for the redefinition and subdivision of the Kralodvorian Stage. Bulletin of Geosciences 92(4), 443-464 (8 figures). Czech Geological Survey, Prague. ISSN 1214-1119. Manuscript received October 28, 2016; accepted in revised form August 7, 2017; published online December 18, 2017; issued December 31, 2017.

Jorge Colmenar, Natural History Museum of Denmark, University of Copenhagen, Øster Voldgade 5-7, 1350 Copenhagen, Denmark; jorgecolmenarlallena@gmail.com • Sofia Pereira, Departamento de Geologia and Instituto Dom Luiz, Faculdade de Ciências, Universidade de Lisboa, 1749-016 Lisboa, Portugal; ardi_eu@hotmail.com•Miguel Pires, Arcodere, Unipessoal Lda., Rua da Sociedade 2, 2350-030 Torres Novas, Portugal; arcodere@gmail.com・Carlos Marques da Silva, Departamento de Geologia and Instituto Dom Luiz, Faculdade de Ciências, Universidade de Lisboa, 1749-016 Lisboa, Portugal; paleo.carlos@fc.ul.pt • Artur Abreu Sá, Departamento de Geologia, Universidade de Trás-os-Montes e Alto Douro, Quinta de Prados 5000-801 Vila Real, Portugal; asa@utad.pt - Timothy P. Young, GeoArch, Unit 6, Block C, Western Industrial Estate, Caerphilly, Wales, UK; tim.young@geoarch.co.uk

The Nicolella Fauna (Pickerill \& Brenchley 1979) was the commonest brachiopod-dominated assemblage throughout high-latitude peri-Gondwana shelves during the Late Ordovician episode of global warming, the Boda Event
(Fortey \& Cocks 2005). This community is widely documented in the upper Katian (Kralodvorian Regional Stage) rocks of the Mediterranean region, from Spain, France and Sardinia (Colmenar 2015 and references therein). Many 
diagnostic brachiopod taxa of the Nicolella Fauna originated in Avalonia, Baltica and Laurentia (Williams 1963, Pickerill \& Brenchley 1979, Harper et al. 2013), located in lower latitudes than High-Latitude peri-Gondwana during the Ordovician. As a consequence of rising temperatures during the Boda Event, carbonate sedimentation encroached High-Latitude peri-Gondwana and these taxa expanded their geographical distribution into this province, replacing endemic taxa (Villas 1985, Villas et al. 2002b, Boucot et al. 2003, Colmenar et al. 2013, Harper et al. 2013, Colmenar 2015) that then became rare or absent in the assemblages, or were displaced to higher latitudes (e.g. Morocco; Colmenar \& Álvaro 2015).

In Portugal, diagnostic brachiopods of the Nicolella Community are known from the Porto de Santa Anna and Ferradosa formations (Young 1988) of the Central Iberian Zone of the Buçaco-Penacova region, Central Portugal (Young 1985, Sá et al. 2011, Colmenar 2015). These occurrences were first documented by Delgado (1870, 1897, 1908), who discovered fossils in these rocks for the first time and provided the earliest lists of fossils from the levels currently included in both formations. The material studied by Delgado was later revised by Young (1985), who established the current accepted lithostratigraphic scheme for the Upper Ordovician of Central Portugal (Young 1988) adding several new outcrops and reporting new fossil occurrences.

The present study reports an exceptional fossil association from the silicified limestones of the upper member of the Ferradosa Formation, the Riba de Cima Member (Young 1988), cropping out in the Penacova-Vila Nova de Poiares region (Fig. 1). The fossiliferous beds yield, in decreasing order of abundance, bryozoans, echinoderms, algae, brachiopods, trilobites and gastropods. Careful sampling during several field campaigns, together with the study of the classical Delgado's fossil collections from these beds housed in the Museu Geológico (LNEG, Lisbon), revealed the presence of previously unrecorded brachiopod and trilobite taxa in Portugal. The biostratigraphical and palaeobiogeographical significance of the new data, especially the brachiopod and trilobite taxa, are discussed. A proposal to subdivide the Kralodvorian Regional Stage is here proposed, together with a reassessment of the Kralodvorian Regional Stage itself and its boundaries.

\section{Geographical and geological setting}

The studied material comes from three localities of the Riba de Cima Member of the Ferradosa Formation, located in Sazes do Lorvăo (Locality 1: 40 $18^{\prime} 25^{\prime \prime} \mathrm{N}, 8^{\circ} 19^{\prime} 53^{\prime \prime} \mathrm{W}$ ) and Ferradosa (Locality 2: $40^{\circ} 15^{\prime} 41^{\prime \prime} \mathrm{N}, 8^{\circ} 14^{\prime} 53^{\prime \prime} \mathrm{W}$ ) localities of Penacova municipality and in Alveite Grande
(Locality 3: $40^{\circ} 13^{\prime} 11^{\prime \prime} \mathrm{N}, 8^{\circ} 12^{\prime} 38^{\prime \prime} \mathrm{W}$ ) locality of Vila Nova de Poiares municipality, both located in the northern part of the Coimbra district (Fig. 1).

The Ordovician rocks of the Buçaco Syncline crop out in the Penacova-Vila Nova de Poiares region, which lies in the western portion of the Central Iberian Zone (CIZ). This syncline comprises two lithostratigraphic sequences separated by an angular unconformity - the Beiras Group, a monotonous, kilometre-thick series of intercalated shales and greywackes Neoproterozoic in age; and the post-Cambrian Palaeozoic metasedimentary sequence, ranging from Lower Ordovician to the Silurian (Oliveira et al. 1992).

The Ferradosa Formation (> $100 \mathrm{~m}$ thick) was defined by Young $(1985,1988)$ in the Penacova region (Central Portugal) and has been assigned to the upper BerounianKralodvorian ( $c a$. middle to upper Katian; Ka2-Ka4 stage slices of the global scale). It crops out in the southern part of the Buçaco Syncline (Penacova to Vila Nova de Poiares sectors). In the type area (near Ferradosa Village) this unit shows a faulted contact with the underlying middle to upper Berounian Louredo Formation (ca. upper Sandbian-middle Katian; Sa2-Ka2 stage slices), but in other sections the Ferradosa Formation exhibits a basal erosive contact, marked by a thin oolitic ironstone layer. This horizon correlates with the oolitic ironstone at the base of the Porto de Santa Anna Formation, in the northernmost part of the Buçaco Syncline.

The Ferradosa Formation comprises two members (from the base to the top): the Poiares Member, composed of decalcified marls (6-10 m thick), and the Riba de Cima Member (up to $100 \mathrm{~m}$ thick), comprising dolomites that are locally silicified.

The Riba de Cima Member is highly fossiliferous, except where the effects of the dolomitization and/or metamorphic processes were more intense that prevented the preservation of the fossils. Its fossil assemblages have been known for more than one hundred years (Delgado 1908) and they were previously partially studied by Young (1985; brachiopods) and Jacinto et al. (2015; echinoderms).

The fossils from Locality 1 (Cabeço Pedrogão - Sazes do Lorvão, Penacova) (Fig. 2A) are from the lower half of the Riba de Cima Member section in this area (Fig. 3). This locality was discovered in 1897 . Young (1985, pp. 87-88) included these beds in his "well-bedded rottenstones" facies. The rocks are highly silicified, but their structure suggests that they were originally carbonates. The petrographic study conducted by Souza-Brandão (1910) identified the presence of cryptocrystalline and other forms of silica (opal), sericite, and kaolinite, although there is still some carbonate preserved. The Riba de Cima Member in this section grades up into a massive, cavernous silicified unit, possibly a silicified equivalent of the massive 

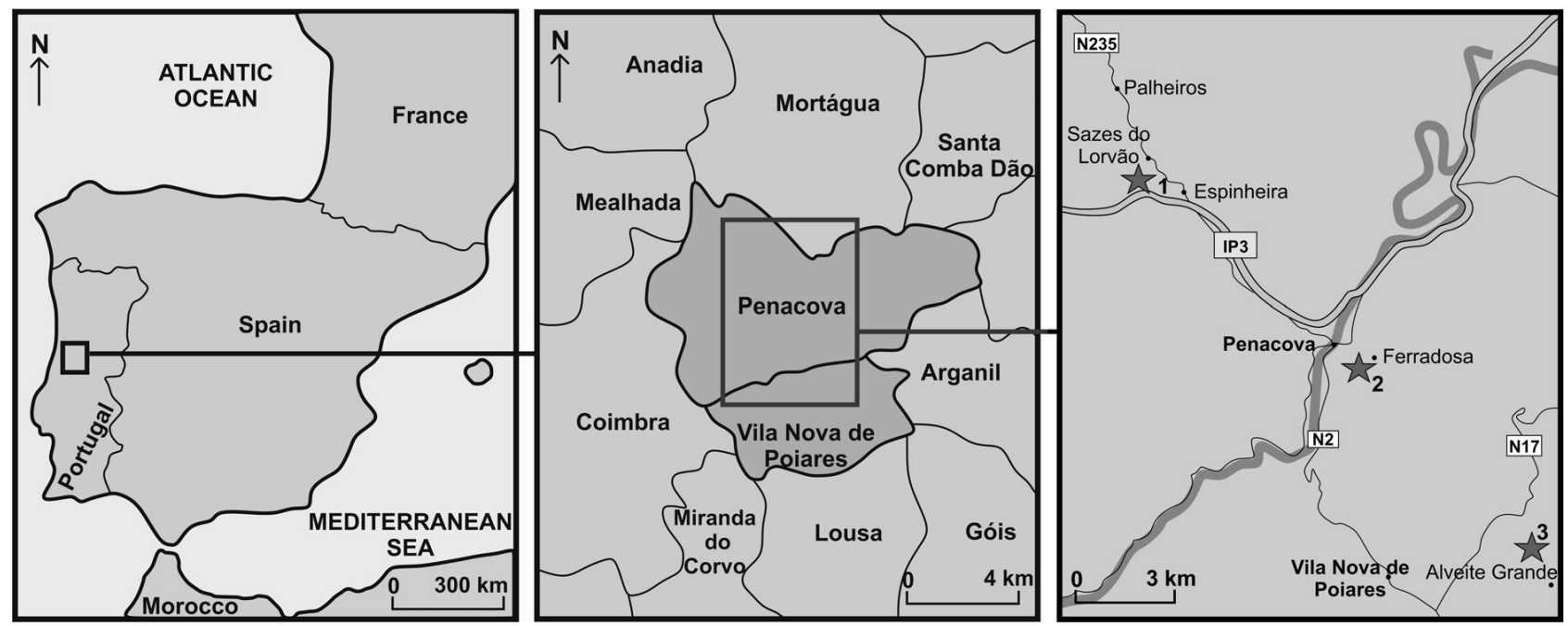

Figure 1. Geographic location of the Riba de Cima Member fossil localities. 1 - Cabeço Pedrogão - Sazes do Lorvão (Penacova); 2 - Ferradosa (Penacova); 3 - Alveite Grande (Vila Nova de Poiares).

dolomites that are exposed approximately $1.2 \mathrm{~km}$ to the northwest, as well as further southeast in the Buçaco Syncline.

The fossils from Locality 2 (Ferradosa, Penacova) came from a roadside outcrop of a highly faulted succession of thinly-bedded silicified rocks (Fig. 2B), probably lying stratigraphically above the massive dolomites (Fig. 3). They are faulted against Silurian mudstones to the west and their relationship to the dolomites to the east is obscured. The locality displays the youngest rocks of the Ordovician succession on the eastern limb of the syncline that are preserved in this part of the area.

The outcrop of the Locality 3 (Alveite Grande, Vila Nova de Poiares) is composed of in situ rock blocks and boulders (Fig. 2C). The lithology is similar to Locality 1, but the rocks are less silicified and their argillaceous component is higher. This locality is interpreted as lying approximately in the middle of the Riba de Cima Member on the eastern limb of the syncline (Fig. 3), but exposure is poor between this locality and the former dolomite quarries $400 \mathrm{~m}$ northwest.

\section{Biostratigraphical and palaeobiogeografical significance of the Riba de Cima Member association}

Most of the taxa recorded in the Riba de Cima Member of the Ferradosa Formation are typical of the Nicolella Fauna. These taxa are considered to have originated in low latitudes and to subsequently expand their geographical distribution to higher latitudes during the mid to late Katian (Ka2-Ka4 stage slices; regional late Berounian-Kralodvorian stages) Boda Event (Fortey \& Cocks 2005). This ex- pansion of the Nicolella Fauna is thought to have wipedout most of the high-latitude peri-Gondwana endemic taxa (Colmenar et al. 2013). As a result, the brachiopod diversity in the peri-Gondwanan shelves increased considerably, with decreasing endemicity (Colmenar 2015). In this context, the biostratigraphical and palaeobiogeographical significance of relevant brachiopod (Figs 4, 6, 7) and trilobite (Figs 5, 7) taxa identified in the Riba de Cima Member association are discussed below. The echinoderm (Figs 5, 7) taxa present in the studied association, despite not having been the subject of a thorough study, are in agreement with records of coeval echinoderm faunas in Spain and Sardinia (Gutiérrez-Marco et al. 1996b; Zamora et al. 2014a, b).

Brachiopods. - The brachiopod genus Nicolella Reed, 1917 is widely represented in Avalonian records throughout the Katian stage (Cheneyan to Rawtheyan regional stages), represented by the species Nicolella actoniae actoniae (J. de C. Sowerby, 1839), N. actoniae multicostata Harper, 1984, N. actoniae obesa Williams, 1963, N. actoniae ramosa Harper, 1984 and N. asteroidea Reed, 1917. The Nicolella genus was also documented in Baltica [Estonia (Vinn 2005), Lithuania (Paškevičius 1994), Norway (Harper et al. 1984)]; Midland Valley terrane [Girvan, Scotland (Williams 1962)]; and Sibumasu, Burma (Cocks \& Zhan 1998)]. In the High-Latitude peri-Gondwanan region only the species $N$. decemcostata Havlíček 1981 from the middle to upper Katian (upper Berounian to Kralodvorian regional stages) Gabian Formation of the Montagne Noire has been defined. The remaining peri-Gondwanan material has been assigned to the Avalonian species (e.g. Havlíček 1981, Villas 1985, Mélou 1990, Sayar \& Cocks 2013). However, its specific assignment is unclear, since several authors recognize important in key diagnostic characters 
such as the interarea attitude (Villas 1985, Mélou 1990), the number of ribs or the growth stage in which the ribs start branching (Colmenar unpublished data) in specimens of the same fossil assemblage. Thus, a comprehensive taxonomic revision focused on these key characters needs to be undertaken in the future, in order to properly classify the Portuguese specimens documented here and the remaining peri-Gondwanan material.

The oldest representatives of Porambonites Pander, 1830 are known from Baltica, namely $P$. intermedius Pander, 1830 from the Floian (Billingen Regional Stage) of Estonia and north-west European Russia and P. trigonus Pander, 1830 (= P. subrecta Pander, 1830; . latissima Pander, 1830; P. parva Pander, 1830) from the Dapingian-lower Darriwilian (Volkhovian Regional Stage) of north-west European Russia. Thus, Porambonites is considered to have originated in Baltica. In the High-Latitude peri-Gondwana realm three Porambonites species have been described: P. havliceki Mergl, 2013 from the upper Arenigian (lower Darriwilian) Šarka Formation of the Czech Republic; P. magnus (Meneghini, 1880) from the middle part of the Kralodvorian Portixeddu Formation of Sardinia and P. dreyfussi Havlíček, 1981 from the upper part of the Kralodvorian Gabian Formation of the Montagne Noire. Also, specimens assigned tentatively to this genus are known in High-Latitude peri-Gondwana probably since the upper Dapingian [Porambonites? sp. from the Klabava Formation, Barrandian area (Mergl 2013)]. P. magnus and $P$. dreyfussi are frequent in peri-Gondwanan Kralodvorian assemblages, especially in Portugal, Spain, France and Sardinia. In the Riba de Cima Member, P. dreyfussi is consistently present in stratigraphically higher levels than the species $P$. magnus. This species succession will be discussed in the following section.

The genus Eoanastrophia Nikiforova \& Sapelnikov, 1973 is known from the lower Sandbian-upper Katian of Altai (Kulkov \& Severgina 1989), the Sandbian-Katian of the Zeravshan Range, Tadzhikistan and from the lower Katian of the Chingiz Terrane (Klenina et al. 1984) and New South Wales (Percival 2009). In High-Latitude peri-Gondwana, this genus is only represented by the species E. pentamera (Meneghini, 1857), reported from the Kralodvorian of the Armorican Massif (Mélou 1990), Montagne Noire (Havlíček 1981), Bohemia (Havlíček \& Mergl 1982, Štorch \& Mergl 1989, Mergl 2011b), Carnic Alps, Sardinia (Havlíček et al. 1987, Leone et al. 1991), Spain (Villas 1985, Gutiérrez-Marco et al. 1996a) and Portugal (Colmenar 2015, this paper).

Saukrodictya Wright, 1964 species are documented from the Upper Ordovician to lower Silurian rocks of Avalonia, Baltica, Siberia and High-Latitude peri-Gondwana. Two species have been described from the periGondwanan fossil record: S. porosa (Havlíček, 1968) from the lower Berounian (Sandbian Global Stage) of Bohemia
(Libeň and Letná formations) and S. reticula (Vinassa de Regny, 1927) from Sardinia (Portixeddu Formation), both recorded from several localities (e.g. Villas 1985, Havlíček et al. 1987, Leone et al. 1991, Gutiérrez-Marco et al. 1996a). Villas (1985) discussed the possible synonymy of $S$. reticulata with the type species $S$. hibernica Wright, 1964, due to similarities in the dorsal internal characters. However, the poor preservation of the type material prevents further comparisons. Sayar \& Cocks (2013) reported a taxon close to $S$. porosa in the Katian "Pendik Bryozoan Shales" of the western Pontides (NW Turkey), co-occurring with specimens assigned to $S$. hibernica. No pictures of this material are available to confirm its assignment to the Bohemian and Avalonian species. The only external mould found in the Riba de Cima Member was assigned to Saukrodictya, but using open nomenclature due to the absence of important internal diagnostic characters.

Dolerorthis Schuchert \& Cooper, 1931 has been reported from the Sandbian of Baltica (Norway; Harper et al. 1984), the upper Sandbian-lower Katian of the Chu-Ili Range and Chingiz Terrane, Kazakhstan (Klenina et al. 1984, Popov et al. 2002), the upper Sandbian-lower Katian of Avalonia (Wales; Hurst 1979), the upper Sandbian of the Midland Valley Terrane (Pomeroy, Ireland; Candela 2003); Sandbian of Girvan, Scotland (Williams 1962) and North China (Rong \& Zhan 1996). Three species of this genus are known in high-latitude peri-Gondwana, D. interplicata (Vinassa de Regny, 1927) and D. maxima (Vinassa de Regny, 1927) from the upper Berounian-Kralodvorian (Katian Global Stage) Portixeddu Formation of Sardinia and D. abeirensis Mélou, 1990 from the upper Kralodvorian (global uppermost Katian) of the Armorican Massif. Dolerorthis interplicata has been reported only from Sardinia. Dolerorthis maxima is also present, besides its type strata, in the Pyrenees (Colmenar 2015), the Montagne Noire (Havlíček 1981, Havlíček et al. 1987, Leone et al. 1991) and the Carnic Alps (Havlíček et al. 1987). Dolerothis abeirensis occurs in the Armorican Massif and in the Portuguese Central Iberian Zone together with Kjaerina (Villasina) meloui that is one of the species proposed below as index taxon for the upper Kralodvorian.

Havlíček (1950) erected Bicuspina based on the species Orthis cava Barrande, 1848 of the lower-middle Berounian [Sandbian-lower Katian (Ka1)] of Bohemia. Only two other species of the genus have been described in peri-Gondwana: Bicuspina multicostellata Havlíček, 1950 from the uppermost middle Berounian (lower Katian, Ka1) of Bohemia, which is also reported in the middle Berounian [upper Sandbian (Sa2)-lower Katian (Ka1)] of the Moroccan Anti-Atlas (Havlíček 1971) and Bicuspina armoricana Mélou, 1990 from the Kralodvorian of the Armorican Massif. The later species is also present in Iberia in both Spain (Gutiérrez-Marco et al. 1996a) and 

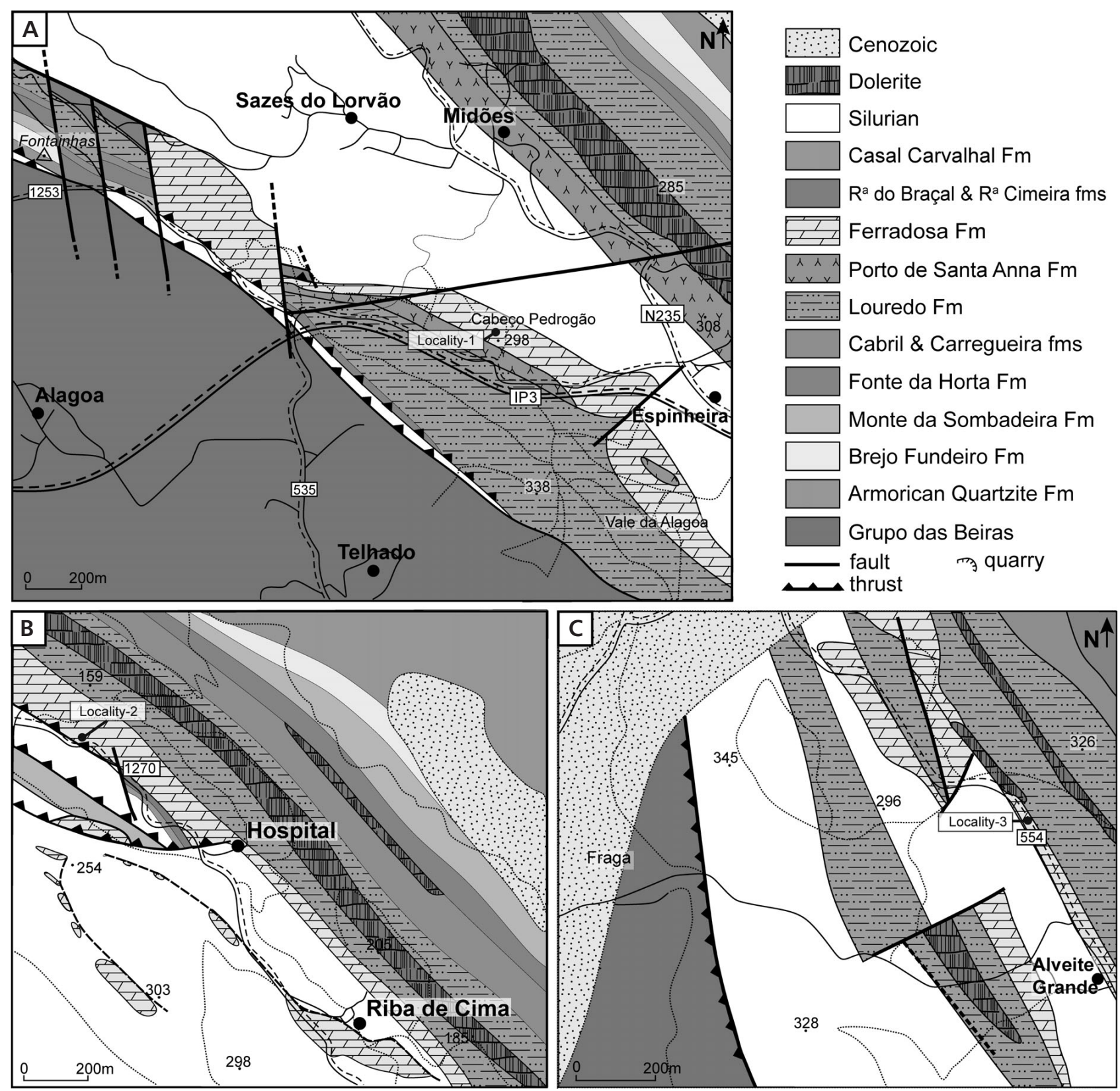

Figure 2. Geological setting of the studied localities. • A - locality 1, Cabeço Pedrogão. • B - locality 2, Ferradosa. • C - locality 3 , Alveite Grande.

probably in Portugal (this paper) and, with uncertainty, in the upper Berounian-Kralodvorian of the Carnic Alps and in Sardinia [reported as B. spiriferoides by Havlíček et al. (1987)]. Apart from peri-Gondwana, this genus is present in the Sandbian of North China (Rong \& Zhan 1996); the lower Katian of Laurentia (Candela 2015); the Burrellian (upper Sandbian) of the Midland Valley Terrane (Pomeroy, Ireland; Candela 2003); the AurelucianBurrellian (upper Sandbian) of Avalonia (N. Wales; Pickerill \& Brenchley 1979); the Sandbian of the Argentinian Precordillera (Benedetto 2003); the upper Sandbian-lower Katian of the Chinghiz Terrane from
Kazakhstan (Popov et al. 2002) and from the Kukruse stage (lower Sandbian) of Baltica (Estonia; Hints \& Rõõmusoks 1997).

Iberomena and Kjaerina (Villasina) emerge in the peri-Gondwanan realm during the late Berounian and thrived there until the end of the Kralodvorian. So far, the occurrences of these two genera are restricted to the fossil record of this domain (Colmenar 2016, fig. 20). Only one species of Iberomena has been described, I. sardoa (Vinassa de Regny, 1927), whereas four species have been ascribed to the Kjaerina (Villasina) subgenus: (1) Kjaerina (V.) pedronaensis Colmenar, 2016, the type species, from 
the upper Berounian-Kralodvorian of Sardinia and reported here for the first time in the Kralodvorian of Portugal; (2) Kjaerina (V.) pyrenaica Colmenar, 2016 from the upper Berounian of the Pyrenees, Spain; (3) Kjaerina (V.) almadenensis (Villas, 1995) known from the Central Iberian Zone (uppermost "Bancos Mixtos", Spain; lower part of the Porto de Santa Anna Formation, Portugal) and from the Armorican Massif (lower and middle parts of the Rosan Formation, assigned to the upper Berounian-lower Kralodvorian - see discussion in next chapter); and (4) Kjaerina (V.) meloui Colmenar, 2016 from the Kralodvorian of the Armorican Massif (limestones of the upper part of the Rosan Formation), present also in the association studied here. The last two species may be used as key elements for subdividing the Kralodvorian (see next chapter).

Trilobites. - The trilobites from the Riba de Cima Member have not been documented before. During the campaign in the Cabeço Pedrogão locality, in 1897 (Locality 1), three trilobite fossils were collected (Fig. 5A, C, H-J). However, they were neither included in Delgado's (1908) fossil lists nor studied by subsequent researchers. The trilobite fossils of the Riba de Cima Member are scarce and poorly preserved, highly fragmented and exfoliated. For this reason, it is extremely difficult to collect identifiable specimens. This preservational style is very similar to that of some trilobite fossils from other peri-Gondwanan Kralodvorian carbonate rocks, particularly the Cystoid Limestone [Spain, Hammann 1992]. The revision of the Cystoid Limestone Formation material studied by Hammann (1992), housed in the Museo de Ciencias Naturales de la Universidad de Zaragoza (Zaragoza, Spain), led to the identification of the fragmentary Portuguese material, although most of the assignments are made using open nomenclature. In addition, the tentative identification of isolated trilobite sclerites was based not only on direct comparison with the Cystoid Limestone Formation specimens, but also on the knowledge of other trilobites from closely located and probably coeval fossil localities in the Penacova region (e.g. Ovalocephalus sp. from Locality 3 and Parillaenus? cf. creber from Locality 1). The lithostratigraphic context of these other localities needs to be confirmed (they are probably assignable to the Poiares Member of the Ferradosa Formation) and for this reason they were not included in this study.

The species Parillaenus? creber (Hammann, 1992), later assigned by this author to the genus Illaenus (Hammann \& Leone 1997), probably does not belong to either of these genera. The assignment to the genus Illaenus was based on Sardinian material, considered by Hammann \& Leone (1997) as conspecific with the Spanish type-material. We prefer to maintain the first doubtful generic assignment to Parillaenus, a genus with the Baltic origin. The main diagnostic dorsal characters and the hypostome configuration suggest a close relationship to Parillaenus (as discussed by Hammann 1992, pp. 57-59). In the course of this study, only isolated sclerites were found (Fig. 5B), but the presence of better preserved material in the Poiares Member, 100 meters west of Locality 1 and in the uppermost Kralodvorian of the Porto de Santa Anna Formation (Colmenar et al. 2016), supports the assignment to P.? creber. Regardless of generic assignment, the species $P$.? creber and related Portuguese and Sardinian specimens represent a morphological group of illaenids characteristic for Kralodvorian assemblages of High-Latitude peri-Gondwana, and no closely related form is known from older rocks of this realm. Therefore, the occurrence of these illaenids probably represents a Baltic immigration related to the Boda Event.

Despite the previous assignment of several species from South China to Cekovia (Zhou \& Zhou 2008 and references therein), an ongoing revision of this genus led to the rejection of their generic assignment. The genus Cekovia is here considered to be endemic to the High-Latitude peri-Gondwana realm. The oldest record of this genus is C. transfuga (Barrande 1852), from the lower Berounian (Sandbian in the global scale) of the Liben Formation of the Czech Republic, with $C$. salteri from the middle Berounian ( $c a$. upper Sandbian-lower Katian) of the Zahořany Formation, presenting the youngest known record in Bohemia (e.g. Bruthansová 2003). However, during the Kralodvorian (upper Katian) Cekovia is one of the most common trilobites in the echinoderm-dominated assemblages of the carbonate units of Ibero-Armorica, i.e. in Portugal (this work), Spain (Robardet 1976, Hafenrichter 1979, Hammann 1992), France (Kerforne 1901, Lebrun 2002) and also in Morocco (Villas et al. 2016). Cekovia sp. (Fig. 5D-E) from the Riba de Cima Member is the first record of this genus in the Kralodvorian of Portugal, and is the most abundant trilobite taxon in this unit.

Amphoriops Hammann \& Leone, 1997 was defined as a subgenus of Thaleops Conrad, 1843, but as suggested by Amati \& Westrop (2006) it, most probably, represents an independent genus. Amphoriops was previously known only from the Kralodvorian of Spain and Sardinia, represented by the species A. inflatus (Hammann, 1992) and A. zoppii (Hammann \& Leone, 1997). Only a single cranidium (Fig. 7S-T) was collected from the Riba de Cima Member, and was (with reserve) assigned to the type-species Amphoriops inflatus known from the Cystoid Limestone Formation, Kralodvorian (upper Katian) of Spain [also documented in the Portixeddu Formation, Katian of Sardinia (Hammann \& Leone 1997)].

In the high-latitude peri-Gondwanan realm, bumastiform trilobites are only known in the Kralodvorian (Hammann 1992). In the Kralodvorian Cystoid Limestone Formation, Hammann (1992) documented "Bumastus" aff. commodus Apollonov, 1980, to which taxon the pygidia 
Jorge Colmenar et al. • A Kralodvorian benthic association from Portugal

Figure 3. $\operatorname{Logs}$ of the studied localities with the stratigraphic ranges of the species. - A - locality 1 , Cabeço Pedrogão - Sazes do Lorvão. • B - locality 2 , Ferradosa, after Young (1988). • C - locality 3, Alveite Grande.
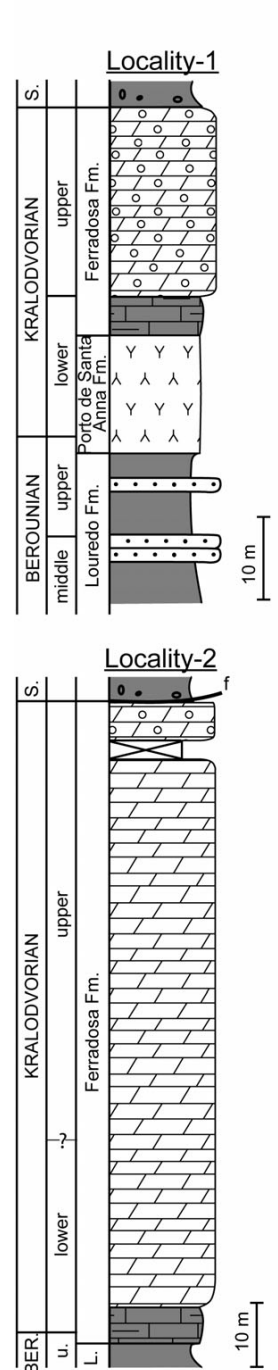

Locality-3

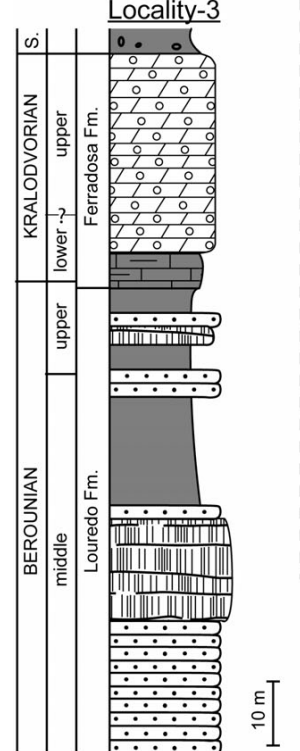

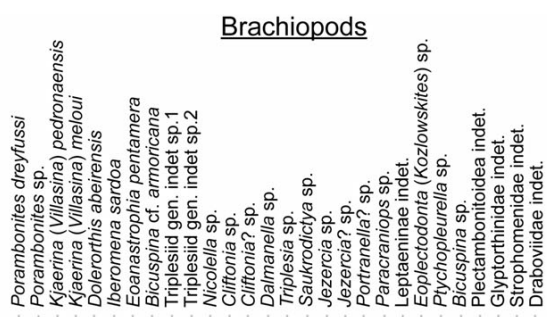

| |||||| ||| ||| ||||

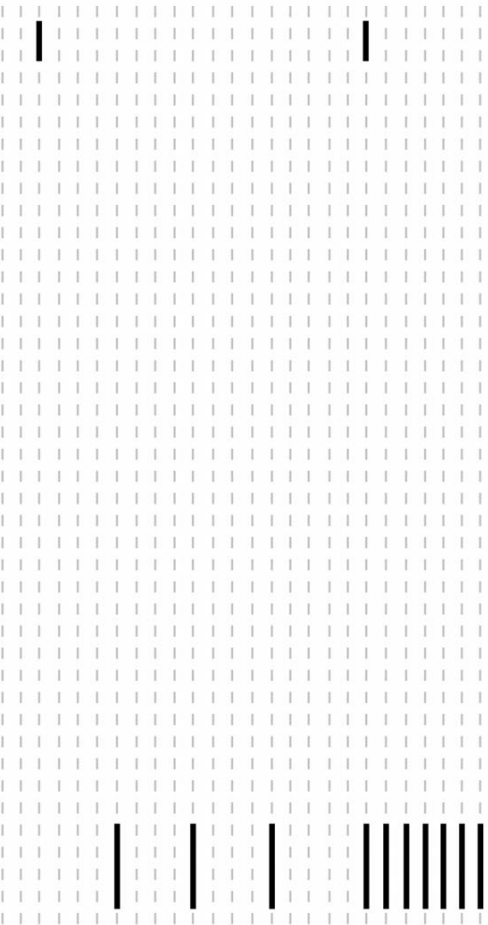

| 11

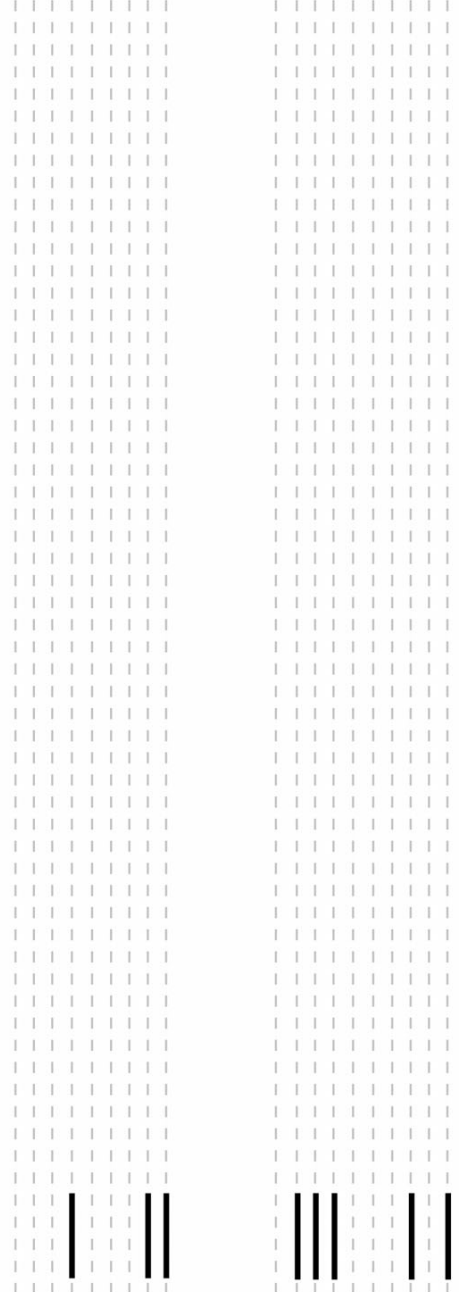

Trilobites
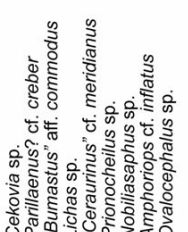

||||||

Echinoderms

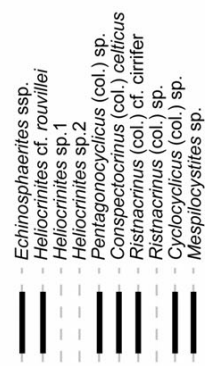

|| || || 
from the Riba de Cima Member (Fig. 5C) are tentatively assigned. The generic assignment of the Spanish specimens was thoroughly discussed by Hammann (1992, p. $80)$. The material from Portugal and Spain bears resemblance with Bumastus commodus from the uppermost Katian Tschokparsk 'Horizon' from Kazakhstan. This is the first record of a bumastiform trilobite in Portugal.

The oldest worldwide known record of the genus Lichas Dalman, 1827 comes from the middle Berounian (ca. upper Sandbian-lower Katian) of Portugal (see Pereira et al. 2015b). A high-latitude peri-Gondwanan origin was suggested for this genus (Pereira et al. 2015b), although the fact that Lichas was first described from Baltica apparently justifies it being considered as Baltic (e.g. Hammann 1992). During the upper Katian, probably related to the global reduction of endemism (the Boda Event), Lichas expanded its geographic distribution, reaching Avalonia and Baltica. Later it became a cosmopolitan genus frequently present in Hirnantian assemblages (Hirnantia Fauna assemblages). This genus is very common in the Kralodvorian trilobite assemblages of the High-Latitude peri-Gondwanan realm which are dominated by illaenids, cheirurids and lichids. In the fossil record of this region, besides the Riba de Cima Member (Figs 3F, G, 5W), the genus was documented as being common in other Kralodvorian (upper Katian) carbonate units of Spain (Cystoid Limestone Formation; Hammann 1992) and Sardinia (Portixeddu Formation; Hammann \& Leone 1997).

A single cranidium (Fig. 5H-J) is here identified as "Ceraurinus" cf. meridianus (Hammann 1992), a taxon previously documented only in the Kralodvorian Cystoid Limestone Formation of Spain. This species was originally assigned to the genus Cyrtometopus (see Hammann 1992, p. 98). This generic assignment is here rejected, based on the more posterior location of the palpebral lobes and non-parallel-sided glabella of the Spanish species. "Ceraurinus" cf. meridianus is related to Ceraurinus-like [sensu Pärnaste 2008] genera, probably representing a new
Cyrtometopinae genus. The Ceraurinus-group genera have their oldest record in the Lower Ordovician of Baltica, but in High-Latitude peri-Gondwana it was recorded in the Kralodvorian only. Therefore, the presence of "Ceraurinus" cf. meridianus in the Riba de Cima Member fossil record is certainly related to the faunal exchanges of the Boda Event, as previously suggested by Hammann (1992).

The Riba de Cima Member of the Ferradosa Formation provided one sole librigena identified as Ovalocephalus sp. This generic identification is based on the comparison with dozens of well-preserved specimens assigned to Ovalocephalus tetrasulcatus (Kielan, 1960) in the Poiares Member (the lower member of the same formation). This species was documented in the upper Katian of Baltica (Poland; Kielan 1960) and peri-Gondwana (Portugal; this paper), Spain (Hammann 1992), Sardinia (Hammann \& Leone 2007) and Turkey (Dean \& Zhou 1988). The conspecific assignment of specimens of Ovalocephalus from China, Kazakhstan, and Kyrgyzstan by Zhou et al. (2010) is considered doubtful, bearing slightly larger L1, adaxially defined by shallower furrows.

Ovalocephalus probably arose in South China, where the genus is known from the Floian (Lower Ordovician), and extended its geographical distribution in successive transgressive events (Zhou et al. 2010). During the upper Katian, with the decreasing endemicity related to the Boda Event, Ovalocephalus became widespread throughout the high-latitude peri-Gondwanan area into the Kazakh terranes and Shibumasu (Portugal, Spain, Sardinia, Turkey, Uzbekistan, Kazakhstan, Kirgizstan, Mongolia and Thailand) and also in Baltica (Poland). In the high-latitude peri-Gondwana, Ovalocephalus is only known from Kralodvorian units (Cystoid Limestone Formation, Spain; the Punta S'Argiola Member of Domusnovas Formation; and the Tuviois Formation, Sardinia), all considered coeval with the Ferradosa Formation.

Finally, a thoracopygon identified as Prionocheilus sp.

Figure 4. Brachiopods from the Riba de Cima Member, upper Kralodvorian (upper Katian) at Locality 2, Cabeço Pedrogão, Sazes do Lorvão (Penacova). • A-D - Porambonites dreyfussi Havlíček, 1981; A-B - ventral valve internal mould (A) and latex cast of the interior (B), MG3214; C-D - latex cast of the exterior (C) and detail of the fenestrate ornament (D) of an indeterminate valve, MG30650. $\bullet$ E - Triplesiidae gen. et sp. nov. 2, latex cast of dorsal valve interior, MG30651. $\bullet \mathrm{F}-\mathrm{J}-$ Kjaerina (Villasina) pedronaensis Colmenar, 2016; F, J - ventral valve internal mould (F) and latex cast of exterior (J), MG30651; G - latex cast of ventral valve interior, MG3219; H - ventral internal mould, MG30652; I - latex cast of the interior of a dorsal valve, MG30653. • K - Portranella? sp. - latex cast of dorsal valve exterior, MG30654. • L-M - Bicuspina cf. armoricana Mélou, 1990. L - ventral valve internal mould, MG30655; M - dorsal valve internal mould, MG30656. • N-Q - Kjaerina (Villasina) meloui Colmenar, 2016; N - ventral valve internal mould, MG30657; O - latex cast of ventral valve exterior, MG30658; P-Q - latex cast of dorsal valve interior (P) and detail of the cardinalia with the meso-cardinal ridge (Q), MG30659. • R-S - Nicolella sp.; R - ventral valve internal mould, MG30660; S - latex cast of dorsal valve interior, MG30661. - T-U - Dolerorthis abeirensis Mélou, 1990, latex cast of exterior (T) and internal mould (U) of a dorsal valve, MG30662. • V-W - Dalmanella sp.; V - dorsal valve internal mould, MG3224; W - ventral valve internal mould, MG30663. • X-Y - Iberomena sardoa (Vinassa de Regny, 1927), latex cast of interior (X) and internal mould (Y) of a dorsal valve, MG30664. • Z - Eoanastrophia pentamera (Meneghini, 1857), dorsal valve internal mould, MG30665. • AA-AD - Jezercia? sp; AA - ventral valve, internal mould, MG30666; AB - dorsal valve, internal mould, MG30667; AC-AD - ventral valve internal mould (AC) and latex cast of exterior (AD), MG3068. • AE - Cliftonia? sp., ventral valve internal mould, MG30669. • AF - Paracraniops sp., ventral valve, internal mould, MG30670. Scale bars represent $2 \mathrm{~mm}$. 

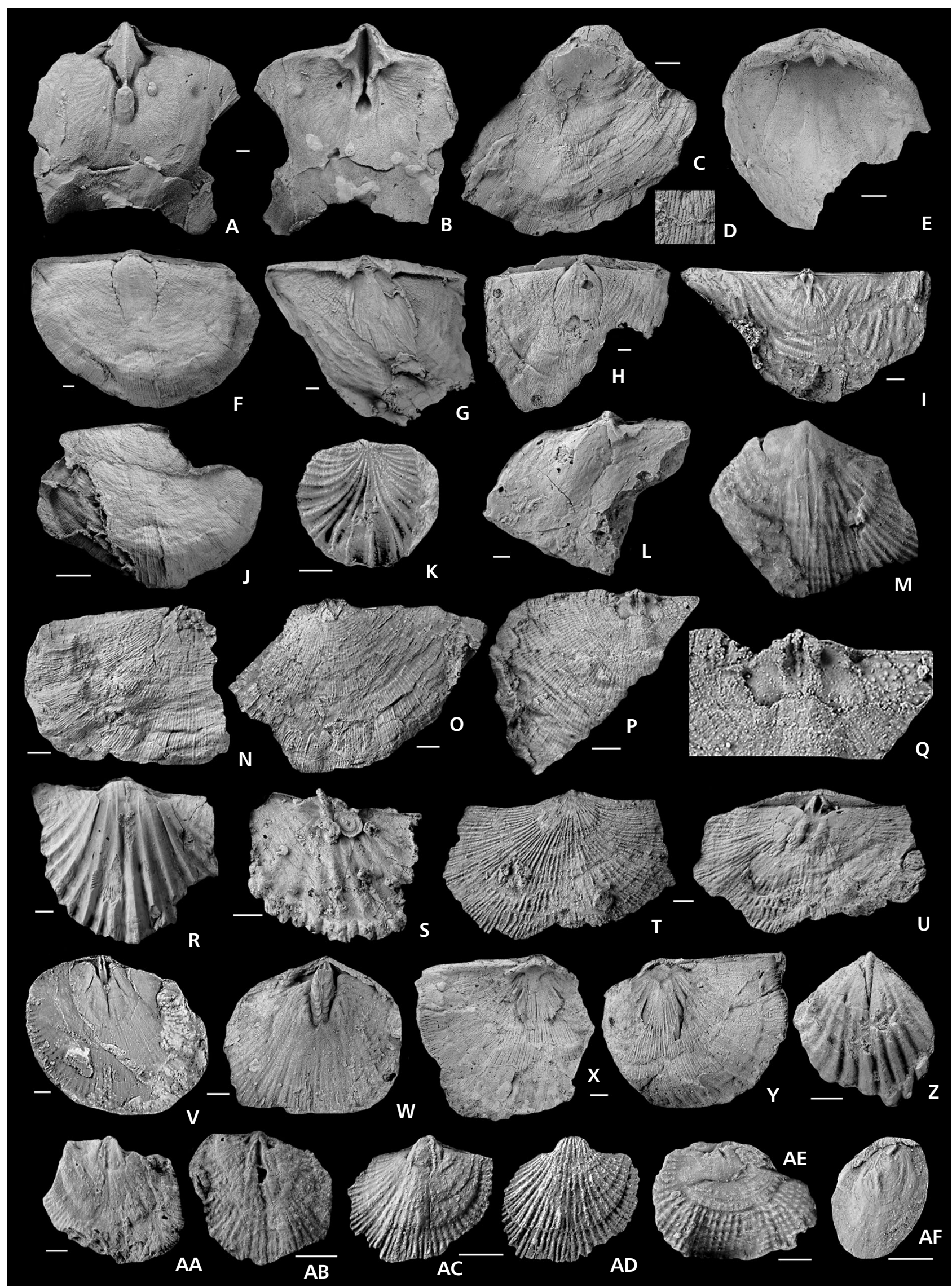
(Fig. 5A) and an exfoliated fragment of Nobiliasaphus sp. (Fig. 5K) were also collected. The genera Prionocheilus and Nobiliasaphus are both considered to have originated in the High-Latitude peri-Gondwana realm, being common in its fossil record from the Lower and the Middle Ordovician, respectively, through to the Kralodvorian ( $c a$. upper Katian). During the late Darriwilian-early Katian, Prionocheilus expanded its geographical distribution to Baltica [e.g. P. nieszkowskii (Schmidt, 1894) of Estonia, and $P$. foveolatus (Törnquist, 1884) of Sweden] and to China (e.g. P. parapulchra Kobayashi, 1951), and during the upper Katian the genus reached other regions, such as Avalonia (e.g. P. cautleyensis Ingham, 1977, from the Cautley Mudstone Formation, Cumbria, England), the Kazakh terranes [e.g. P. inermis Kolobova in Sokolov \& Yolkin (1978), of the Obikalon Member of the Shakhriomon Formation, Uzbekistan, and $P$. solitus Apollonov 1974 of the upper Katian?-Hirnantian of Kazakhstan]. In the Kralodvorian rocks of High-Latitude peri-Gondwana, Prionocheilus has been previously documented in Spain [P. obtusum (M'Coy, 1846), Cystoid Limestone Formation] and in Sardinia $[P$. inermis Kolobova in Sokolov \& Yolkin, (1978), Portixeddu Formation and $P$. rutilus Hammann \& Leone, 1997, Cyclopygid Bed of the Punta S'Argiola Member of the Domusnovas Formation].

The trilobite association of the Riba de Cima Member of the Ferradosa Formation supports the assignment of this unit to the Kralodvorian (ca. upper Katian). Several taxa are documented in Portugal for the first time: Parillaenus? cf. creber, Amphoriops cf. inflatus, "Bumastus" aff. commodus, "Ceraurinus" cf. meridianus and Ovalocephalus sp. All of them are exclusively known from the Kralodvorian of high-latitude Gondwana (with the exception of Ovalocephalus, but the specific identification of O. tetrasulcatus in the Poiares Member also limits its range to the Kralodvorian). In Ibero-Armorica, these five taxa were previously documented from the Cystoid Limestone Formation of Spain (Hammann 1992) only. The remaining identified trilobites (Cekovia sp., Lichas sp., Prionocheilus sp. and Nobiliasaphus sp.) also characterize the Kralodvorian assemblages of this region. It is important to highlight that the Kralodvorian trilobite assemblages of the high-latitude peri-Gondwanan realm (specially from Ibero-Armorica and Morocco), although bearing some taxa considered to have originated in other regions (namely Baltica, Kazakh terranes and South China), were still composed largely by hitherto endemic representatives (e.g. Cekovia, Lichas, Prionocheilus, Nobiliasaphus, as discussed above). Some of these peri-Gondwana trilobite taxa expanded their geographical distribution during the late Katian, with their faunal shifts being coeval with the "poleward invasion" (sensu Fortey \& Cocks 2005) related to the Boda Event. This trilobite "reverse invasion" has been overlooked in previous works (e.g. Hammann 1992, Fortey \& Cocks 2005) as a result of different generic assignments and/or inaccurate determination of the region where they evolved, with some taxa now considered peri-Gondwanan in origin (e.g. Lichas, Radnoria, ?Ulugtella; Pereira et al. 2015a, b).

\section{Problematic issues on the Kralodvorian Regional Stage and its redefinition}

The Kralodvorian Regional Stage was established by Havlíček \& Marek (1973), originally as a series of regional status, corresponding to the Králův Dvůr Formation. Its lower boundary with the underlying upper Berounian was defined by a sharp change in sedimentation and faunal community at the base of the Králův Dvůr Formation (Fatka et al. 1995) representing possible deepening of the Prague Basin.

The validity of the Kralodvorian Regional Stage has been questioned by Kraft et al. (2015). They argued that the Kralodvorian represents a specific and probably heterochronous succession of facies and faunal associations that reflect distinct conditions widespread in peri-Gondwanan Europe (and Gondwanan North Africa) at that time, clearly different from those of the underlying and overlying units. Gutiérrez-Marco et al. (2017) agreed with Kraft et al. (2015) that these criteria are irrelevant for the definition of a formal chronostratigraphic unit, but they highlighted that those criteria are extremely useful for inter-regional correlations between successions with a scarcity or absence of graptolites, long ranging conodont zones, or inconclusive data obtained from other groups.

Kraft et al. (2015) provided new graptolite data and proposed a tentative correlation of the Králův Dvůr Formation with the regional British and global stages. The first key taxon is the graptolite Anticostia teres that probably occurs in the basal Podolí 'Horizon' of the Králův Dvưr Formation, but it has certainly been found in the following metres of overlying black shales in the lower part of the formation. This taxon occurs in Pleurograptus linearis Zone strata in Baltica (Bornholm and Sweden) (Kraft et al. 2015). However, since the range of the $P$. linearis Biozone in England and Wales (Ka2-Ka3) extends from the regional uppermost Caradoc until (at least) the middle part of the Rawtheyan Substage of the type Ashgillian (Rickards 2002, 2004; Zalasiewicz et al. 2009), the correlation proposed by these authors with the Caradoc-Ashgill boundary of the regional British scheme has been considered imprecise (Gutiérrez-Marco et al. 2017). Štorch \& Mergl (1989) placed the Kralodvorian-Kosovian boundary in the Prague Basin by the sudden extinction of the high diversity Proboscisambon Community ("Perník Bed") and 


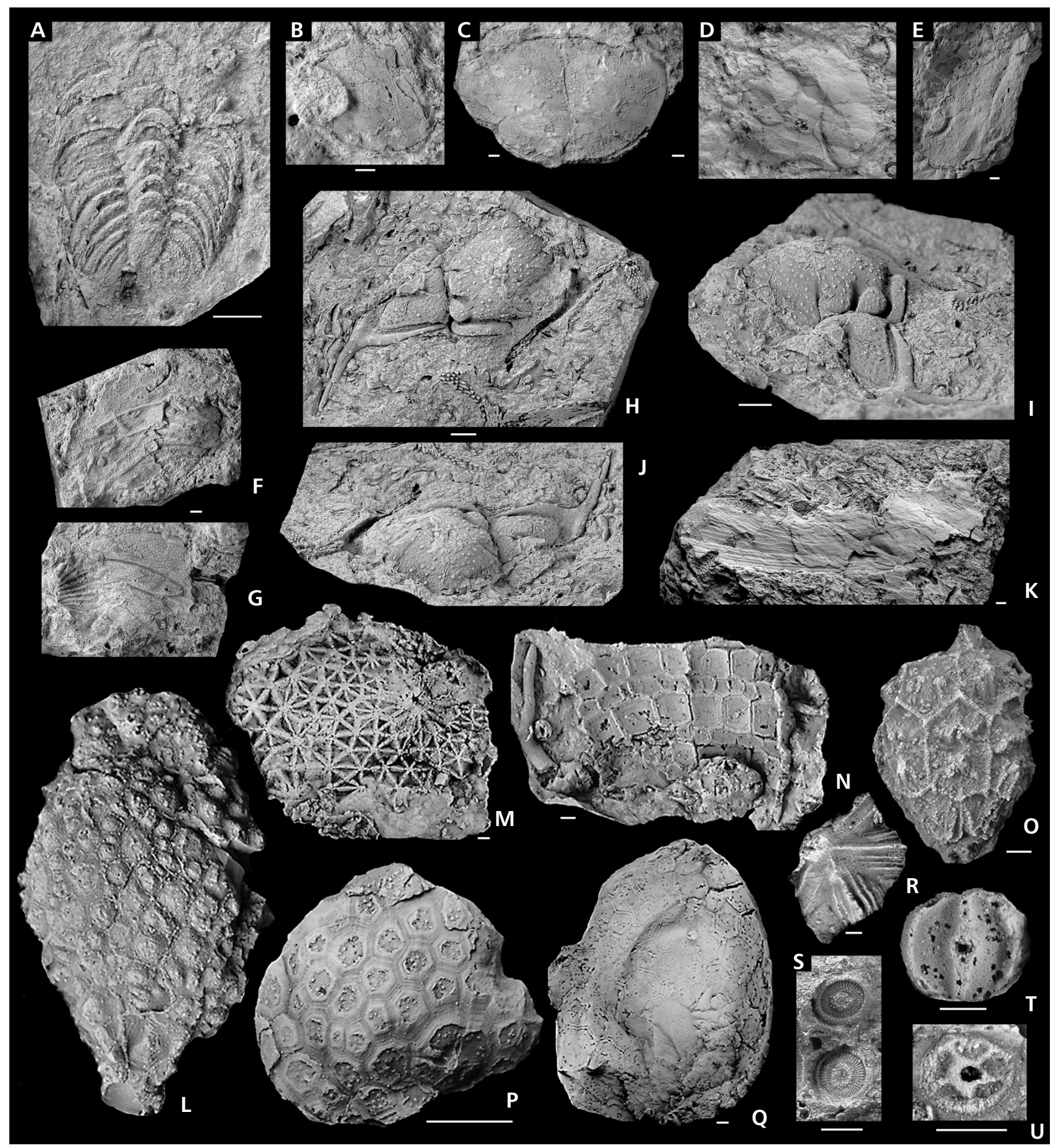

Figure 5. Trilobites and echinoderms from the Riba de Cima Member, upper Kralodvorian (upper Katian) at Locality 2, Cabeço Pedrogão, Sazes do Lorvão (Penacova). • A - Prionocheilus sp., internal mould of a thoracopygon, MG3205. • B - Parillaenus? creber (Hammann, 1992), internal mould of a librigena, MG15711. • C - "Bumastus" aff. commodus Apollonov, 1980, internal mould of a pygidium, MG3271. • D - Cekovia sp., internal mould of a cranidium, MG30585. • F-G - Lichas sp., external mould (F) and internal mould (G) of a fragment of a pygidium, MG30626. • H-J - "Ceraurinus" cf. meridianus Hammann, 1992, internal mould of a cranidium in dorsal (H), lateroblique (I) and anteroblique (J) views, MG170. $\bullet$ K - Nobiliasaphus sp., internal mould of an exfoliated fragment, MG30576. $\bullet$ L, P-Q - Echinosphaerites spp.; internal mould of an elongated theca with variably sized and irregular in outline plates (L), MG3236; internal mould of a theca (P), MG3231a; internal mould of a theca (Q), MG3231b. • M - Heliocrinites cf. rouvillei von Koenen, 1886 , latex cast of a theca, MG3232. $\bullet \mathrm{N}$ - Diploporita indet., latex cast of a fragment of theca showing primary and secondary plate cycles, MG3236. $\bullet$ O Hemicosmitida indet., complete silicified theca in lateral view, MG30671. $\bullet$ R - Macrocystella sp., latex cast of an incomplete thecal plate, MG3233. $\bullet$ Pentagonocyclicus (col.) sp., external mould of two disarticulated columnal plates, MG30672. $\bullet$ T Ristnacrinus (col.) cf. cirrifer Le Menn, 1973, latex cast of a columnal plate, MG3241. $\bullet$ - Conspectocrinus (col.) celticus Le Menn, 1973, latex cast of a columnal plate, MG3245. Scale bars represent 2 mm. 


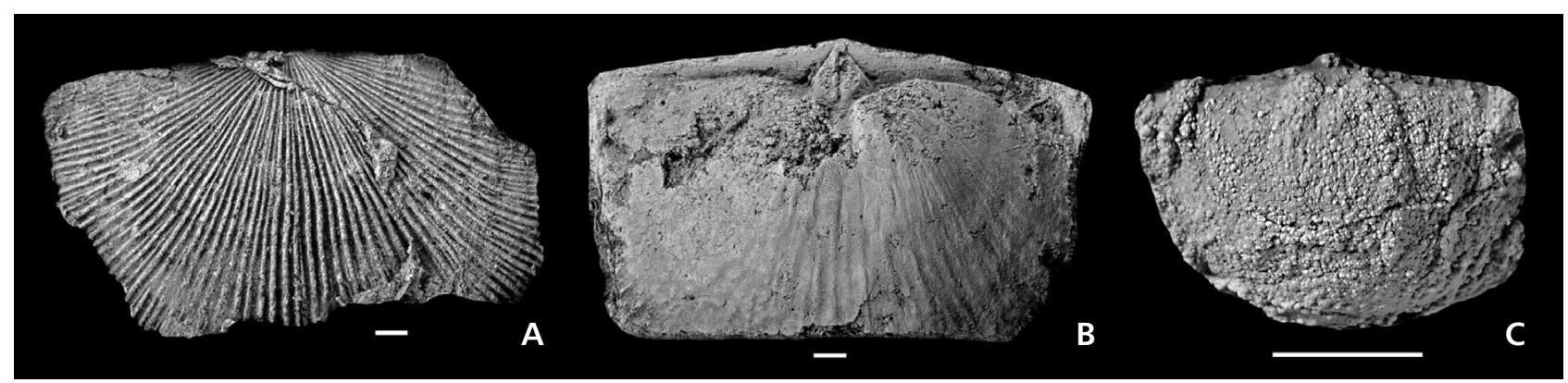

Figure 6. Brachiopods from the Riba de Cima Member, upper Kralodvorian (upper Katian) at Locality 3, Ferradosa (Penacova). A-B - Dolerorthis aberirensis Mélou, 1990, latex cast of the exterior (A) and internal mould (B) of a dorsal valve, MG30673. • C - Eoplectodonta (Kozlowskites) sp., internal mould of a ventral valve, MG30674. Scale bars represent $2 \mathrm{~mm}$.

its replacement by the Mucronaspis Community in the overlying bed. These faunistic replacements, together with the drastic lithological changes recorded in the basin, related with the onset of the Hirnantian glaciation, allowed Štorch \& Mergl (1989) to correlate the Kralodvorian-Kosovian boundary with the Anglo-Scandic Rawtheyan-Hirnantian boundary. Thus, Štorch (1990) placed the Kralodvorian-Kosovian boundary just above the "Perník Bed", criteria followed by several authors since then to place the Katian-Hirnantian boundary (Mergl 2011a, Kraft et al. 2015). The presence of Metabolograptus ojsuensis (indicative of the Hirnantian sensu Kraft et al. 2015) in the Králův Dvůr Formation is also relevant; its first occurrence is at the basal layer of the shale overlying the "Perník Bed" which marks the upper limit of the Kralodvorian (Kraft et al. 2015). However, the first occurrence of typical Hirnantia Fauna in the Barrandian area has been registered in the topmost Králův Dvůr Formation (Mergl 2011a), in levels slightly above the occurrence of the Mucronaspis Community. In addition, Mitchel et al. (2011) detected a positive peak in $\delta^{13} C_{\text {org }}$ in the shale interval between the top of the "Perník Bed" and the diamictite at the base of the overlying Kosov Formation, which has been interpreted as the Hirnantian Isotopic Curve Excursion (HICE). Mergl (2011b), after a taphonomical study of the small bioclasts of the "Perník Bed", suggesting that all bioclasts were transported in higher or lesser extent, inter- preted this bed as a result of the deposition of a distal mudflow, which brought fine bioclasts into deeper parts of the basin, related with the effects of a glacio-eustatic sea level drop. This interpretation suggests that the "Perník Bed" deposition should be likely isochronous with the onset of the Hirnantian glaciation, and thus, if this is true the upper limit of the Kralodvorian would lie above the Katian-Hirnantian boundary. The fauna occurring in the "Perník Bed", the Proboscisambon Fauna (Štorch \& Mergl 1989), which corresponds to the small sized Foliomena Fauna (Harper 1979), is typical from deep environments (BA4-BA5 or deeper; Rong et al. 1999 and references therein). Also larger size taxa occur such as the brachiopods Eoanastrophia and Hindella and the trilobites Mucronaspis, Duftonia, Actinopeltis, Gravicalymene, Octillaenus, Marekolithus, rarely complete. An alternative, and in our opinion, more plausible explanation is that the bioclasts of the "Perník Bed" were transported basinward just by simple marine flows or transport downslope the platform, and then accumulated in deep environments bearing a mixture of big brachiopod and trilobite remains (always fragmented or incomplete), probably originally from shallower environments [Eoanastrophia is a characteristic genus of the Nicolella Fauna, lower BA3 (Colmenar 2016); Hindella is a genus usually present in BA2-upper BA3 benthic assemblages (Rong \& Harper 1988); Actinopeltis and Octillaenus are usually associated

Figure 7. Brachiopods, trilobites and echinoderms from the Riba de Cima Member, upper Kralodvorian (upper Katian) at Locality 4, Alveite Grande (Vila Nova de Poiares). A A-C - Nicolella sp.; A - latex cast of dorsal valve exterior, MG30675; B - latex cast of dorsal valve exterior, MG30676; C - dorsal valve interior, MG30677. • D - Ptychopleurella sp., latex cast of a dorsal valve exterior showing the characteristic lamellate ornament of this taxon, MG30678. • E-Bicuspina sp. internal mould of an incomplete ventral valve with part of the shell preserved, MG30679. • F-G - Triplesia sp.; F-internal mould of a ventral valve, MG30680; G - internal mould of a dorsal valve, MG30681. • H - Strophomenidae indet., internal mould of a dorsal valve, MG30682. • I - Iberomena sardoa (Vinassa de Regny, 1927), internal mould of a dorsal valve, MG30683. • J-M - Dalmanella sp.; J - internal mould of a ventral valve, MG30684; K-M - latex cast of exterior (K), internal mould (L) and latex cast of interior (M) of a dorsal valve, MG30685. - N - Plectambonitoidea indet. internal mould of a ventral valve, MG30686. • O-P - Jezercia sp.; O - internal mould of a dorsal valve, MG30687; P - internal mould of a ventral valve, MG30688. $\bullet$ Q - Draboviidae indet. - internal mould of an incomplete dorsal valve, MG30689. $\bullet$ R - Cliftonia? sp. ventral valve with the shell preserved, MG30690. $\bullet$ S-T - Amphoriops cf. inflatus (Hammann, 1992), internal mould of a cranidium in anteroblique (S) and dorsal (T) views, MG30612. $\bullet \mathrm{U}-$ Ovalocephalus sp., internal mould of a librigena with the eye preserved, MG30574. $\bullet \mathrm{V}-$ Lichas sp., internal mould of an incomplete cranidium, MG30575. • W - Mespilocystites sp., latex cast of a complete specimen in oral view, MG30691. $\bullet$ X - Heliocrinites sp. 1 , latex cast 


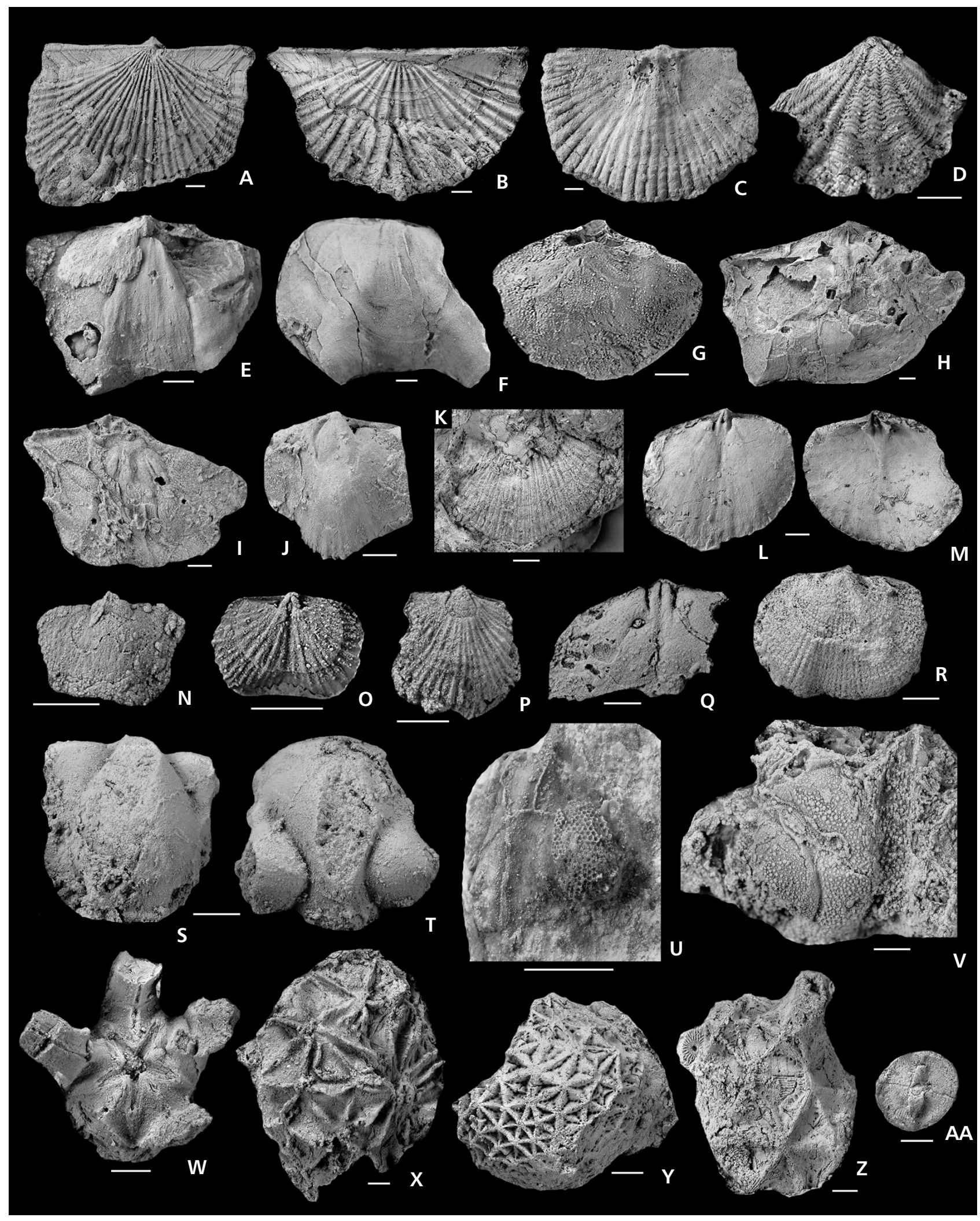

of an incomplete theca in lateral view, MG30692. • Y - Heliocrinites cf. rouvillei von Koenen, 1886, latex cast of an incomplete theca in lateral view, MG30693. - Z - Heliocrinites sp. 2, latex cast of an incomplete theca in lateral view showing the proximal part of one arm, MG30694. -AA - Ristnacrinus (col.) sp., latex cast of a columnal plate, MG30695. Scale bars represent $2 \mathrm{~mm}$. 
with taxa that characterizes the Cheirurid-Illaenid Community, typical of shallow shelf environments (Hammann \& Leone 2007)], together with deep-water fauna (Foliomena Fauna and small trilobites) also probably partially transported downslope. This downslope transportation was also previously proposed for bryozoans (Mergl 2011b). With this simple explanation the Katian-Hirnantian boundary is reasonable to be placed, as both faunistic and isotopic evidences suggest (Štorch \& Mergl 1989, Štorch 1990, Mergl 2011a, Mitchell et al. 2011, Kraft et al.2015), in the above the "Perník Bed".

All these data discussed above, indicate that the Kralodvorian Regional Stage, as it is used in modern chronostratigraphy (Gutiérrez-Marco et al. 2017), does not necessarily coincide with the Králův Dvůr Formation.

The lowermost Králův Dvůr Formation is characterized by a discontinuous oolitic ironstone horizon, the "Podoli Ore Horizon". This horizon has yielded a very scarce and poorly known trilobite association. Budil et al. (2011, p. 4) suggested that there is an apparent mixing of species, with "...survivals from the underlying Bohdalec Formation combined with the late Katian taxa [Onnia cf. ultima, Chlustinia mikulasi (= keyserlingi fide Vaněk \& Valíček 2001), Selenopeltis sp., Octillaenus? sp., Actinopeltis cf. gryphus, Duftonia juspa konika nomen nudum... and Kloucekia sp.]". However, Onnia, Chlustinia and Duftonia? juspa Šnajdr, 1982 are already present in the upper Berounian Bohdalec Formation (Vaněk \& Vokáč 1997), represented by species which are morphologically very similar to the ones listed by Budil et al. (2011). In addition, all trilobite specimens from the "Podolí Ore Horizon" are generally poorly preserved and do not enable definitive determination. In our opinion, the trilobites from the Podolí 'Horizon' actually constitute rather an upper Berounian assemblage, as previously indicated by Budil et al. (2011). This discontinuous "horizon" also yielded a low diversity brachiopod assemblage (Mikuláš 1985, Havlíček in Chlupáč et al. 1998), with Aegiromena, Jezercia and Gelidorthis, typical elements of the brachiopod Aegiromena-Drabovia Fauna (Havlíček, 1982) widely represented in the upper Berounian Bohdalec Formation. The brachiopod Leptaena, also present in this "horizon", is unknown in older Berounian rocks of the Bohemian area (M. Mergl personal communication). Above this horizon, the Králův Dvůr sequence is dominated by the "deeper water" Rafanoglossa Community, being the most abundant the brachiopods Rafanoglossa and Chonetoidea and the trilobites Amphitryon, Kloucekia, Flexicalymene, Tretaspis, Dionide and some cyclopygids and illaenids. About 20-30 metres below the "Perník Bed", in the upper half of the Králův Dvůr Formation at the Levín section, Foliomena folium, Dedzetina and Eoplectodonta (Kozlowskites), characteristic brachiopods of the Foliomena Fauna, occur for the first time (M. Mergl personal communication). These brachiopods sometimes co-occur with Rafanoglossa specimens (M. Mergl personal communication). Above the Foliomena folium bearing beds, Chonetoidea and several trilobites such as Ampyx, Tretaspis, Zetillaenus, cyclopygids and others occur (M. Mergl personal communication). After few meters of greenish shales without fauna and few centimetres below the Hirnantian Kosov Formation, at the "Perník Bed," the Proboscisambon Fauna occurs. As we mention above, this fauna corresponds as well to the deep water Foliomena Fauna. Just above the "Perník Bed" in the grey-green claystones and in siltstones of the very last centimetres (ca. decimetres to metres of succession in total) of the formation, were identified two distinct fossil associations: one known as the Mucronaspis Fauna (Štorch \& Mergl 1989), occurring in the claystones, and the other assigned to the Hirnantia Fauna, described by Mergl (2011a) in the siltstones 5-7 cm below the diamictite at the base of the overlying Kosov Formation (Kraft et al. 2015).

Besides the lithological and facies changes, the disappearance of the brachiopods of the Aegiromena-Drabovia Fauna was one of the criteria chosen for the definition of the Kralodvorian Regional Stage (Havlíček \& Marek 1973). After the occurrence of these clearly upper Berounian taxa at the basal horizon of the Králův Dvưr Formation, and by the occurrence near the top of the Hirnantia Fauna, the limits designated for the Kralodvorian Regional Stage must be reassessed. Here we propose the use of the top of the Podolí 'Horizon', the last level with upper Berounian taxa, as the lower limit of the Kralodvorian in the Bohemian area. When the "Podolí Ore Horizon" is not present at the base of the Králův Dvưr Formation, the LAD (Last Appearance Datum) of the Aegiromena-Drabovia brachiopod fauna and the Berounian-like trilobites will mark the top of the Berounian. In addition, we propose the top of the "Perník Bed," as we discussed above, as the upper limit, supported by the occurrence of Hirnantian graptolites and brachiopods above this bed.

In other High-Latitude peri-Gondwanan areas the deepening that occurred in the Bohemian area, marking the beginning of the Kralodvorian, is not recorded. Instead, the Kralodvorian may be recognized by the development of carbonate platforms (e.g. southwestern and central Europe, the Ghadamis Basin of Libya and the eastern Tafilalt region of the Moroccan Anti-Atlas; Gutiérrez-Marco et al. 2017 and references therein), replacing the previously siliciclastic-dominated platforms. This sedimentary change is interpreted as having been caused by the late Katian global warming Boda Event (Fortey \& Cocks 2005) and its related factors, such as increase of water temperatures, rise of sea level and development of high-latitude carbonate platforms (Colmenar 2015) that flooded extensively flat emerged areas interrupting the siliciclastic input. 


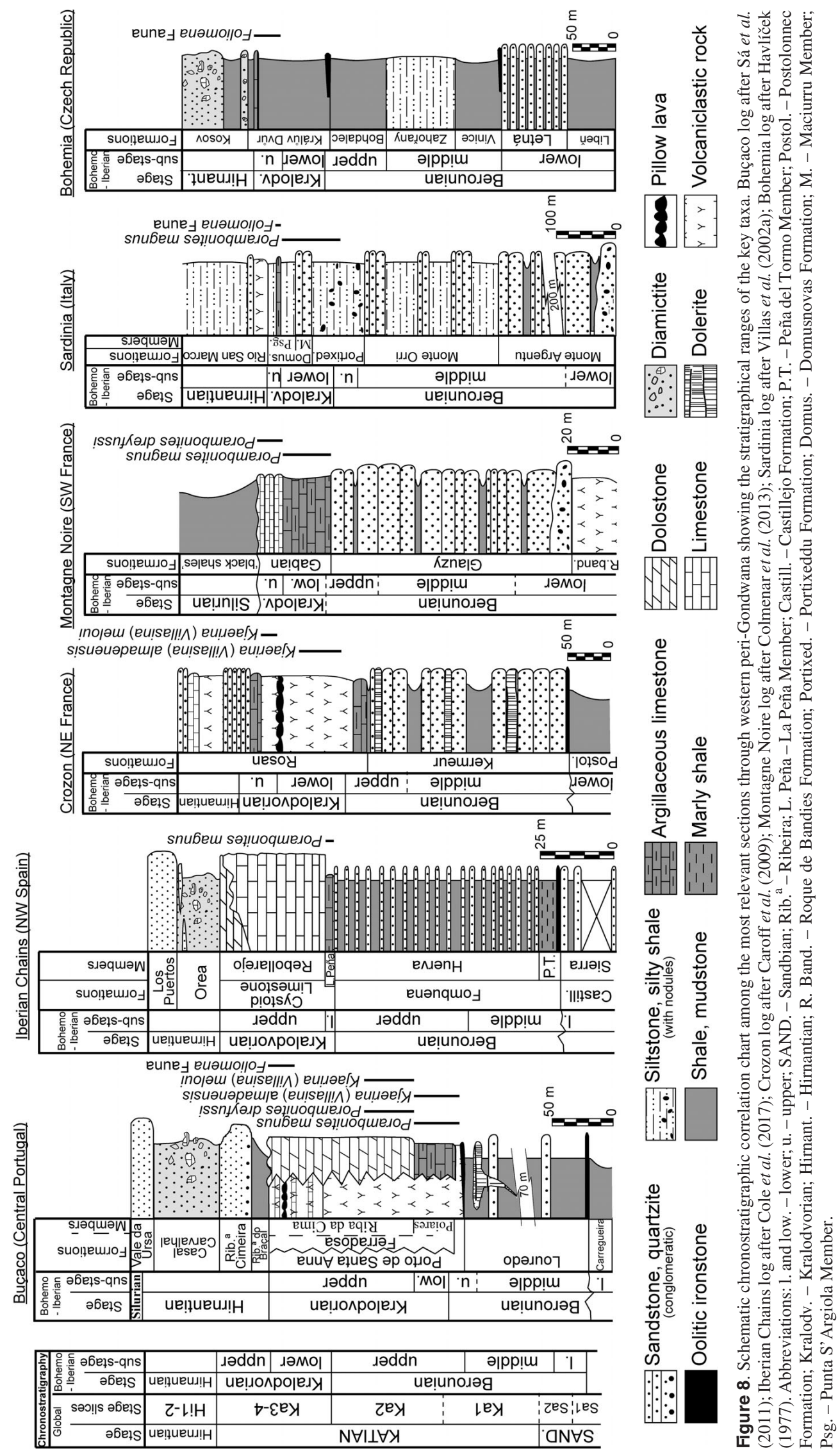


Shifts of the brachiopod fauna have been also detected in this realm that are marked by the appearance of taxa with low-latitude origins (roughly the Nicolella Fauna), which replaced progressively, during the Kralodvorian, the typical endemic biotas (characterized by aegiromenids, draboviids and heterorthids) that inhabited the high-latitude peri-Gondwana during the upper Berounian. However, among trilobites these faunal exchanges seem to have been different, with the arrival of low-latitude taxa being coeval with the geographical expansion of high-latitude Gondwanan trilobites to other domains including Avalonia, Baltica, the Kazakh terranes and South China.

The arrival of the Nicolella Fauna in high-latitude peri-Gondwana seems to have been diachronous, controlled by ecological conditions (Gutiérrez-Marco et al. 2017). This would explain the coexistence in the peri-Gondwanan record of upper Berounian endemic taxa with the Boda Event "immigrants" (Nicolella Fauna) as it has been documented in the Portixeddu Formation of Sardinia and in the Gabian Formation of the Montagne Noire (Colmenar, 2015 and references therein). These co-occurrences of typical upper Berounian taxa with the "immigrants" that have previously been considered exclusively Kralodvorian, makes establishing the location of the Berounian-Kralodvorian boundary in high-latitude peri-Gondwana very difficult. The upper boundary of the Kralodvorian with the Hirnantian is, however, recognisable either by the presence of glaciogenic sediments or by the presence of the Hirnantia Fauna itself.

Furthermore, in high-latitude peri-Gondwanan fossil record, the general scarcity of graptolites and conodonts and the largely endemic nature of the shelly faunas, add difficulties for correlating the successions in this region with the global chronostratigraphy (Gutiérrez-Marco et al. 2015). The correlation for the Kralodvorian Regional Stage with the international scale can be attempted only when the conodont Amorphognathus ordovicicus (the FAD of which marks the beginning of the upper Katian, Ka3 stage slice; Bergström et al. 2009) is recognizable, requiring the development of appropriate litho- and biofacies, potentially distant from its FAD (GutiérrezMarco et al. 2015). In addition, the absence of the graptolite Dicellograptus complanatus in peri-Gondwana (excepting for few isolated and stratigraphically unclear occurrences in France; Gutiérrez-Marco et al. 2015), the appearance of which characterizes the Ka4 stage slice (Bergström et al. 2009), makes correlation with the uppermost Katian problematic.

In Morocco, due to the absence of suitable conditions for the settlement of the Nicolella Fauna (Colmenar 2015) and the very shallow onshore shelf facies (GutiérrezMarco et al. 2017) that prevent the occurrence in that region of the deep water Foliomena Fauna, the Kralodvorian is marked by the presence of the Mucronaspis
termieri-Flexicalymene ouzregui assemblage (GutiérrezMarco et al. 2017).

\section{Proposal for the subdivision of the Kralodvorian Regional Stage}

Herein we propose a subdivision of the Kralodvorian Regional Stage based on brachiopod occurrences, which allows an even more precise correlation within western periGondwana. The division of the Kralodvorian into a lower and upper part must take into consideration that the occurrence of brachiopod assemblages is usually facies controlled. For this reason, we propose both deep- and shallow-water brachiopod markers, which are widespread throughout the main high-latitude peri-Gondwana localities and sections (Fig. 8). In addition, it is important to note that it would be necessary to complement this proposed subdivision with the stratigraphic ranges and occurrences of other fossil groups such as graptolites, conodonts and chitinozoans, among others.

Deep-water facies. - The Foliomena Fauna (Harper 1979) is known from lower-mid Katian deep-water facies of low-mid latitude settings (Rong et al. 1999 and references therein), but at higher latitudes (peri-Gondwana) it is only known from the uppermost Kralodvorian. The first report of this fauna in high-latitude peri-Gondwana came from the "Perník Bed" of the upper part of the Králův Dvůr Formation (Havlíček \& Mergl 1982), which, as discussed above, represents the uppermost Kralodvorian in the Barrandian area. The Foliomena Fauna was also described from the "Cyclopygid Bed" of the Punta S'Argiola Member of the Domusnovas Formation of Sardinia (Villas et al. 2002a), approximately $35 \mathrm{~m}$ above the Sardic FAD of Amorphognatus ordovicicus, and about 18-20 m below the conformably overlying Hirnantian Rio San Marco Formation (Leone et al. 1991, Villas et al. 2002a). The Foliomena Fauna was recently identified in the uppermost Porto de Santa Anna Formation (Colmenar et al. 2016) in approximately coeval but deeper facies than those containing the fauna described in this paper (which includes a few minute, and perhaps transported, brachiopods such as Jezercia see above - from the Foliomena Fauna).

Based on the records from Bohemia, Iberia and Sardinia, the occurrences of the Foliomena Fauna in high-latitude peri-Gondwana seems to be restricted to the uppermost Kralodvorian. This is probably due to the fact that the deep marine conditions required for the settlement of this fauna only occurred in this realm during the late Kralodvorian, possibly related to the transgression linked to the Boda Event.

Here we propose to use the records of the Foliomena Fauna as an indicator of the upper Kralodvorian. In add- 
ition, the presence in Bohemia of brachiopods of the Rafanoglossa Community could be indicative of the lower Kralodvorian in the Bohemian area. However, the cooccurrence of Rafanoglossa with Foliomena folium at the Levín section (M. Mergl personal communication) has to be investigated in other areas that, until now such cooccurrence has not been registered. In the same way, the use of this community as a marker of the lower Kralodvorian in deep water facies development of periGondwanan regions must be subject to findings or more thorough studies of this community outside Bohemia).

Shallow-water facies. - The brachiopod taxa Porambonites and Kjaerina (Villasina) are found in shallower facies and they are represented by species that have different stratigraphical ranges within the Kralodvorian. The biostratigraphical distribution of these brachiopods could therefore provide additional criteria for subdivision of the stage. Only two species of Porambonites are known in the Kralodvorian of high-latitude peri-Gondwana - Porambonites magnus (Meneghini, 1980), originally described from Sardinia and Porambonites dreyfussi Havlíček, 1981, from the Montagne Noire. Porambonites dreyfussi has been found always above P. magnus in the Kralodvorian (Havlíček 1981) Gabian Formation (Colmenar et al. 2013). This pattern is also observed in the Portuguese Kralodvorian sequences (this paper). Porambonites dreyfussi always occurs in the Riba de Cima Member of the Ferradosa Formation (Kralodvorian) whereas P. magnus is restricted to the lower part of the Porto de Santa Anna Formation (uppermost Berounian to lower Kralodvorian) and to the Poiares Member (uppermost Berounian to lower Kralodvorian), lower member of the Ferradosa Formation (Young 1985, Colmenar 2015).

Currently, Kjaerina (Villasina) includes four species. Among them, Kjaerina (V.) meloui (Colmenar, 2016), from the Rosan Formation of the Armorican Massif is exclusively Kralodvorian. On the other hand, Kjaerina $(V$.) almadenensis (Villas, 1995) from the Spanish Central Iberian Zone ranges from the uppermost Berounian to the Kralodvorian. In the Rosan Formation Kjaerina (V.) meloui has only been recorded from above the levels of occurrence of Kjaerina $(V$.) almadenensis within the Rosan Formation (Colmenar 2016). This situation was also observed in Portugal (this paper) where Kjaerina (V.) meloui is restricted to the Riba de Cima Member of the Ferradosa Formation and Kjaerina (V.) almadenensis to the lower part of the Porto de Santa Anna Formation and to the Poiares Member.

These criteria suggest that, in areas where the deep water facies containing the Foliomena Fauna is absent, the presence in shallow facies of either of the brachiopod species Porambonites dreyfussi or Kjaerina (Villasina) meloui may indicate an upper Kralodvorian age, whereas the pres- ence of Porambonites magnus and/or Kjaerina (V.) almadenensis could be diagnostic of the lower Kralodvorian.

\section{Conclusions}

The study of Kralodvorian brachiopod-dominated associations from rocks of the Portuguese Central Iberian Zone, together with a comparison of other benthic associations from the main Ordovician successions of peri-Gondwana, has allowed redefining the base and top of the Kralodvorian Regional Stage. The proposed informal subdivision of this stage, based on shallow- and deep-water brachiopod occurrences, may be complemented by further investigation, in these key successions, of other biostratigraphically relevant fossil groups such as graptolites, conodonts and chitinozoans.

\section{Acknowledgements}

We thank M. Ramalho (Museu Geológico de Lisboa) and J. Ignacio Canudo (Universidad de Zaragoza) for granting access to fossil collections under their care; Ana Jacinto, Cristiana Esteves, Cristina Pires, Eduardo Soares, Gonçalo Silvério and Linda Inês for helping with the field work; Ana Jacinto and Samuel Zamora (Instituto Geológico y Minero de España, IGME) for helping with the identifications of the echinoderms; J.J. Álvaro (Instituto de Geociencias, CSIC-UCM) for helping with fieldwork in Penacova; J.C. Gutiérrez-Marco (CSIC-Spanish National Research Council) for fruitful discussions on the division of the Kralodvorian. SP is supported by a FCT $\mathrm{PhD}$ grant (SFRH/BD/73722/2010). JC is supported by the IBEROR projects CGL2012-39471/BTE and CGL2013-48877-P from the Spanish MINECO and by a VILLUM Foundations Young Investigator Programme. This is a contribution to the IGCP 653 Project.

\section{References}

Amati, L. \& Westrop, S. 2006. Sedimentary facies and trilobite biofacies along an Ordovician shelf to basin gradient, Viola Group, South-Central Oklahoma. Palaios 21, 516-529.

DOI 10.2110/palo.2006.p06-069

Apollonov, M.K. 1974. Ashgillskie trilobity Kazachstana. 136 pp. lzdatel'stvo Nauka Kasachskoj ASSR, Alma-Ata. [in Russian]

Apollonov, M.K. 1980. Klass Trilobita. Trilobyty, 86-118. In Apollonov, M.K., Bandaletov, S.M. \& Nikitin, J.F. (eds) The Ordovician-Silurian boundary in Kazakhstan. lzdatel'stvo Nauka Kasachskoj ASSR, Alma-Ata. [in Russian]

BARRANDE, J. 1848. Über die Brachiopoden der silurischen Schichten von Böhmen. Naturwissen-schaftliche Abhandlungen 2, 155-256. 
BARRANDE, J. 1852. Systême silurien du centre de la Bohême. Ière Partie. Recherches paléontologiques. 1. Crustacés: Trilobites. 935 pp. Privately published, Prague \& Paris. DOI 10.5962/bhl.title.82327

Benedetto, J.L. 2003. Ordovician fossils of Argentina. 561 pp. Secretaria de Ciencia y Tecnología, Universidad Nacional de Córdoba, Córdoba.

Bergström, S.M., Chen, X., Gutiérrez-Marco, J.C. \& Dronov, A. 2009. The new chronostratigraphic classification of the Ordovician System and its relations to major regional series and stages and to $\delta^{13} \mathrm{C}$ chemostratigraphy. Lethaia 42, 97-107. DOI 10.1111/j.1502-3931.2008.00136.x

Boucot, A.J., Rong, J.Y., Chen, X. \& Scotese, C.R. 2003. Pre-Hirnantian Ashgill climatically warm event in the Mediterranean region. Lethaia 36, 119-132. DOI 10.1080/00241160310001245

Bruthansová, J. 2003. The trilobite Family Illaenidae Hawle et Corda, 1847 from the Ordovician of the Prague Basin (Czech Republic). Transactions of the Royal Society of Edinburgh 93, 167-190. DOI 10.1017/S0263593300000407

Budil, P., Fatka, O., Mergl, M. \& David, M. 2011. Trilobite biostratigraphy of the Králův Dvůr Formation (upper Katian, Prague Basin, Czech Republic): Global faunal changes or facies-related distribution? Geologické výzkumy na Moravě a ve Slezsku 18(1), 4-10.

CAndela, Y. 2003. Late Ordovician brachiopods from the Bardahessiagh Formation of Pomeroy, Ireland. Monograph of the Palaeontographical Society 156, 1-95.

CAndela, Y. 2015. Evolution of Laurentian brachiopod faunas during the Ordovician Phanerozoic sea level maximum. Earth-Science Reviews 141, 27-44. DOI 10.1016/j.earscirev.2014.11.012

Caroff, M., Vidal, M., Bénard, A. \& Darboux, J.R. 2009. A late-Ordovician phreatomagmatic complex in marine soft-substrate environment: The Crozon volcanic system, Armorican Massif (France). Journal of Volcanology and Geothermal Research 184(3-4), 351-366. DOI 10.1016/j.jvolgeores.2009.05.002

Cocks, L.R.M. \& ZHAN, R.B. 1998. Caradoc brachiopods from the Shan States, Burma (Myanmar). Bulletin of the British Museum (Natural History), Geology 54(2), 109-130.

Cole, S., Ausich, W., Colmenar, J., \& Zamora, S. 2017. Filling the Gondwanan gap: Paleobiogeographic implications of new crinoids from the Castillejo and Fombuena formations (Middle and Upper Ordovician, Iberian Chains, Spain). Journal of Paleontology 91(4), 715-734. DOI 10.1017/jpa.2016.135

Colmenar, J. 2015. The arrival of brachiopods of the Nicolella Community to the Mediterranean margin of Gondwana during the Late Ordovician: palaeogeographical and palaeoecological implications. Palaeogeography, Palaeoclimatology, Palaeoecology 428, 12-20.

DOI 10.1016/j.palaeo.2015.03.030

Colmenar, J. 2016. Ordovician Rafinesquininae (Brachiopoda, Rhynchonelliformea) from peri-Gondwana. Acta Palaeontologica Polonica 61(2), 293-326.

DOI 10.4202/app.00102.2014
Colmenar, J. \& Álvaro, J.J. 2015 Integrated brachiopod-based bioevents and sequence-stratigraphic framework for a Late Ordovician subpolar platform, eastern Anti-Atlas, Morocco. Geological Magazine 152(4), 603-620.

DOI 10.1017/S0016756814000533

Colmenar, J, Pereira, S., Sá, A.A., Silva, C.M. Da \& Young, T.P. 2016. First report of the Foliomena Fauna in Portugal. The Palaeontological Association $60^{\text {th }}$ Annual Meeting 2016, Programmes and Abstracts, 62-63.

Colmenar, J., Villas, E. \& Vizcaïno, D. 2013. Upper Ordovician brachiopods from the Montagne Noire (France): endemic Gondwanan predecessors of Prehirnantian low-latitude immigrants. Bulletin of Geosciences 88(1), 153-174. DOI 10.3140/bull.geosci. 1352

CONRAD, T.A. 1843. Observations on the lead.bearing limestone of Wisconsin and description of a new genus of trilobites and fifteen new Silurian fossils. Proceedings of the Acadamy of Natural Sciences of Philadephia 1, 329-335.

Dalman, J.W. 1827. Om palaeaderna, eller de så kallade trilobiterna. Kungliga SvenskaVetenskapsakademiens Handlingar, v. for 1826, 113-294.

DeAn, W.T. \& Zhou, Z. 1988. Upper Ordovician trilobites from the Zap Valley, south-east Turkey. Palaeontology 31, 621-649.

Delgado, J.F.N. 1870. Breves apontamentos sobre os terrenos paleozoicos do nosso paiz. Revista de Obras Publicas e Minas 1, 3-4, 6, 15-27, 98-110, 168-175.

Delgado, J.F.N. 1897. Fauna Silúrica de Portugal. Novas observações ácerca de Lichas (Uralichas) Ribeiroi. Memória da Secção dos Trabalhos Geológicos de Portugal, $1-74$.

Delgado, J.F.N. 1908. Système silurique du Portugal. Étude de stratigraphie paléontologique. 245 pp. Memórias da Commissão dos Serviços geologicos de Portugal, Lisbon.

Fatka, O., Kraft, J., Kraft, P., Mergl, M., Mikuláš, R. \& ŠTorCh, P. 1995. Ordovician of the Prague Basin: stratigraphy and development, 241-244. In COOPER, J.D., Droser, M.L. \& FINNEY, S.C. (eds) Ordovician Oddyssey: short papers for the $7^{\text {th }}$ ISOS, Las Vegas. Pacific Section Society for Sedimentary Geology, Fullerton.

Fortey, R.A. \& Cocks, L.R.M. 2005. Late Ordovician global warming - The Boda event. Geological Society of America Bulletin 33, 405-408. DOI 10.1130/G21180.1

Gutiérrez-Marco, J.C., Aramburu, C., Arbizu, M., Méndez-Bedia, I., RÁbano, I., \& Villas, E. 1996a. Rasgos estratigráficos de la sucesion del Ordovícico Superior en Portilla de Luna (Zona Cantábrica, noroeste de España). Geogaceta 20, 11-14.

Gutiérrez-Marco, J.C., Chauvel, J. \& Meléndez, B. $1996 \mathrm{~b}$. Nuevos equinodermos (cistideos y blastozoos) del Ordovícico de la Cordillera Ibérica (NE España). Revista Española de Paleontología 11(1), 100-119.

Gutiérrez-Marco, J.C., SÁ, A.A., García-Bellido, D. \& RÁBANO, I. 2017. The Bohemo-Iberian regional chronostratigraphic scale for the Ordovician System and 
palaeontological correlations within South Gondwana. Lethaia 50, 258-295. DOI 10.1111/let.12197

Gutiérrez-Marco, J.C., SÁ, A.A., Rábano, I., Sarmiento, G.N., García-Bellido, D.C., Bernárdez, E., Lorenzo, S., Villas, E., Jiménez-Sánchez, A., Colmenar, J. \& Zamora, S. 2015. Iberian Ordovician and its international correlation. Stratigraphy 12(3-4), 257-263.

Hafenrichter, M. 1979. Paläontologisch-Ökologische un Lithofazielle Untersuchungen des "Ashgill-Kalkes" (Jungordovizium in Spanien). Arbeiten aus dem Paläontologischen Institut Würzburg 3, 1-139.

HammanN, W. 1992. The Ordovician trilobites from the Iberian Chains in the Province of Aragón, NE Spain. I. The trilobites of the Cystoid Limestone (Ashgill Series). Beringeria 6, $1-219$.

Hammann, W. \& Leone, F. 1997. Trilobites of the post-Sardic (Upper Ordovician) sequence of southern Sardinia. Part I. Beringeria 20, 3-217.

Hamman, W., Leone, F. 2007. The trilobites from the 'post-Sardic' (Upper Ordovician) sequence of the Iglesiente, Arburese and Sarrabus region, southern Sardinia, Italy. Part II. Beringeria 38, 1-138.

HARPER, D.A.T. 1979. The Environmental Significance of Some Faunal Changes in the Upper Ardmillan Succession (Upper Ordovician), Girvan, Scotland, 439-445. In Harris, A.L., Holland, C.H. \& Leake, B.E. (eds) The Caledonides of the British Isles-Reviewed. Geological Society of London, Special Publication 8.

Harper, D.A.T. 1984. Brachiopods from the Upper Ardmillan succession (Ordovician) of the Girvan district, Scotland. Part 1. Monograph of the Palaeontographical Society 136, $1-78$.

Harper, D.A.T., Owen, A.W. \& Williams, S.H. 1984. The Middle Ordovician of the Oslo region, Norway, 34. the type Nakholmen Formation (upper Caradoc), Oslo, and its faunal significance. Norsk Geologisk Tidsskrift 64, 293-312.

Harper, D.A.T., Rasmussen, C.M.Ø., Liljeroth, M., Blodgett, R.B., Candela, Y., Jin, J., Percival, I.G., Rong, J.Y., Villas, E. \& ZHAN, R.B. 2013. Biodiversity, biogeography and phylogeography of Ordovician rhynchonelliform brachiopods, 127-144. In Harper, D.A.T. \& Servais, T. (eds) Early Palaeozoic Biogeography and Palaeogeography. Geological Society London, Memoirs 38.

HaVlíčEK, V. 1950. The Ordovician brachiopoda from Bohemia. Rozpravy Ústředního ústavu geologického 12, 1-135.

HAVLÍČEK, V. 1968. New brachiopods from the lower Caradoc of Bohemia. Věstník Ústředního ústavu geologického 43, 123-125.

HAVlíčEK, V. 1971. Brachiopodes de l'Ordovicien du Maroc. Notes et Mémoires du Service géologique du Maroc 230, $1-135$.

HAVLíčEK, V. 1977. Brachiopods of the order Orthida in Czechoslovakia. Rozpravy Ústředního ústavu geologického 44, $1-327$.

HAvlíČEK, V. 1981. Upper Ordovician brachiopods from the
Montagne Noire. Paleontographica, Abteilung A 176, $1-34$.

HaVlíčEK, V. 1982. Ordovician of Bohemia: Development of the Prague Basin and its benthic communities. Sborník geologických Věd, Geologie 37, 103-136.

HavlíčeK, V. 1998. Prague Basin, 39-133. In Chlupáč, I., HavlíčeK, V., Křiž, J., Kukal, Z. \& ŠTorch, P. (eds) Palaeozoic of the Barrandian (Cambrian-Devonian). Czech Geological Survey, Prague.

HavlíčEK, V. \& MAReK, L. 1973. Bohemian Ordovician and its international correlation. Časopis pro Mineralogii a Geologii $18,225-232$.

HavlíčEK, V. \& Mergl, M. 1982. Deep water shelly fauna in the latest Kralodvorian (upper Ordovician, Bohemia). Věstník Ústředního ústavu geologického 57, 37-46.

HavlíčEK, V., KŘiž, J. \& Serpagli, E. 1987. Upper Ordovician brachiopod assemblages of the Carnic Alps, Middle Carinthia and Sardinia. Bollettino della Societŕ Paleontologica Italiana 25, 277-311.

Hints, L. \& Rõõmusoks, A. 1997. Articulated brachiopods, 226-228. In Raukas, A. \& Teedumäe, A. (eds) Geology and Mineral Resources of Estonia. Estonian Academy Publishers, Tallinn.

HuRST, J.M. 1979. The stratigraphy and brachiopods of the upper part of the type Caradoc of south Salop. Bulletin of the British Museum (Natural History), Geology 32, 183-304.

InGHAM, J.K. 1977. The Upper Ordovician trilobites from the Cautley and Dent districts of Westmoreland and Yorkshire. Monograph of the Palaeontographical Society 546, part of volume 130 for 1976, 89-121.

JaCinto, A.F.M., GutiérReZ-MArCo, J.C. \& ZAMORA, S. 2015. Understanding the oral area of derived stemmed echinoderms, 75-78. In Zamora, S. \& Rábano, I. (eds) Progress in Echinoderm Palaeobiology. Cuadernos del Museo Geominero, 19.

KERFORNE, F. 1901. Étude de la région silurique occidentale de la presqu'île de Crozon. 234 pp. Ph.D. thesis, Université Rénnes, Rénnes, France.

Kielan, Z. 1960. Upper Ordovician trilobites from Poland and some related forms from Bohemia and Scandinavia. Palaeontologia Polonica 11, 1-198.

Kobayashi, T. 1951. On the Ordovician trilobites in central China. Journal of the Faculty of Science of the Imperial University of Tokyo, section 2: Geology 8(1), 1-87.

Klenina, L.N., Nikitin, I.F. \& Popov, L.E. 1984. Brachiopods and Biostratigraphy of the Middle and Upper Ordovician of the Chinghiz Ranges. 196 pp. lzdatel'stvo Nauka Kasachskoj SSR, Alma-Ata. [in Russian]

Koenen, A. von 1886. Über neue Cystideen aus den CaradocSchichten der Gegend von Montpellier. Neues Jahrbuch für Mineralogie, Geologie und Paläontologie 2, 246-254.

Kolobova, I.M. 1978. Klass Trilobita, 126-144. In Sokolov, B.S. \& Yolkin, E.A (eds) Progranichnye sloi ordovika i silura Altae-Sayanskoj oblasti i Tyan-Shanya. 397 pp. Trudy Instituta Geologii i Geofiziki, Sibirskoe Otdelenie, Akademiya Nauk SSSR. [in Russian] 
Kraft, P., Štorch, P. \& Mitchell, C.E. 2015. Graptolites of the Králův Dvůr Formation (mid Katian to earliest Hirnantian, Czech Republic). Bulletin of Geosciences 90, 195-225.

Kulkov, N.P. \& Severgina, L.G. 1989. Ordovician and Early Silurian Stratigraphy and Brachiopods from Gorny Altai. 221 pp. lzdatel'stvo Nauka, Moscow. [in Russian]

Lebrun, P. 2002. Trilobites de France. Tome 1 - Généralités sur les trilobites, Massif armoricain (Bretagne, Normandie, Vendée). Minéraux \& Fossiles, Hors-série 14, 1-132.

Le Menn, J. 1973. In Chauvel, J. \& Le Menn, J. (eds) Echinodermes de l'Ordovicien supérieur de Coat-Carrec, Argol (Finistère). Bulletin de la Societé Géologique et Minéralogique de Bretagne (C) 4(1), 39-61.

Leone, F., Hammann, W., Serpagli, E. \& Villas, E. 1991. Lithostratigraphic units and biostratigraphy of the post-sardic Ordovician sequence in south-west Sadinia. Bolletino della Società Paleontologica Italiana 30, 201-235.

M'Coy, F. 1846. A synopsis of the Silurian fossils of Ireland. 72 pp. University Press, Dublin.

MéLou, M. 1990. Brachiopodes articulés de la coupe de l'île de Rosan (Crozon, Finistère). Formation des Tufs et calcaires de Rosan (Caradoc-Ashgill). Geobios 23(5), 539-579. DOI 10.1016/0016-6995(90)80025-B

Meneghini, G. 1857. Paleontologie de l'île de Sardaigne, 81-222. In Marmora, A. de la (ed.) Voyage en Sardaigne ou description statistique, physique et politique de cette île avec des recherches sur les productions naturelles et ses antiquités, troisiéme partie, suite de la description géologique II. Imprimerie Royale, Turin \& Paris.

Meneghini, G. 1880. Nuovi fossili siluriani di Sardegna. Memorie della reale Accademia dei Lincei series 3(5), 216-229.

Mergl, M. 2011a. Earliest occurrence of the Hirnantia Fauna in the Prague Basin (Czech Republic). Bulletin of Geosciences 86(1), 63-70. DOI 10.3140/bull.geosci.1245

Mergl, M. 2011b. Faunal turnover near the Katian/Hirnantian boundary in the Prague Basin (Czech Republic), 359-366. In Gutiérrez-Marco, J.C., Rábano, I. \& García-Bellido, D. (eds) Ordovician of the World. Cuadernos del Museo Geominero 14.

Mergl, M. 2013. Porambonites havliceki sp. nov., a new brachiopod from the Śárka Formation (Darriwilian) from Bohemia and its contribution to early history of the Porambonitidae. Acta Musei Nationalis Pragae, Series B, Historia Naturalis 69 (1-2), 87-92.

Mikuláš, 1985. The brachiopods of the Podolí ore horizon (Upper Ordovician, Barrandian area). Časopis Národního Muzea, Řada přirodovédná 154, 51-54.

Mitchell, C.E., Štorch, P., Holmden, C., Melchin, M.J. \& GutiérreZ-Marco, J.C. 2011. New stable isotope data and fossils from the Hirnantian Stage in Bohemia and Spain: implications for correlation and paleoclimate, 371-378. In Gutiérrez-Marco, J.C., Rábano, I. \& García-Bellido, D. (eds) Ordovician of the World. Cuadernos del Museo Geominero 14.

NikIFOROVA, O.I. \& SAPELNIKOV, V.P. 1973. Nekotorye drevnie pentameridy Zeravshanskogo khrebta [Some fossil pentamerids from the Zeravshan Range], 64-81. In Sapelnikov, V.P. \& Chuvashov, B.I. (eds) Materialy po paleontologii srednego Paleozoia Uralo-Tian'shan'skoi oblasti. Trudy Instituta Geologii i Geokhimii Ural'skii Nauchnyi Tsentra 99.

Oliveira, J.T., Pereira, E., Piçarra, J.M., Young, T. \& Romano, M. 1992. O Paleozóico Inferior de Portugal: síntese da estratigrafia e da evoluçăo paleogeográfica, 359-375. In Gutiérrez-Marco, J.C., SaAvedra, J. \& Rábano, I. (eds) Paleozóico Inferior de Ibero-América. Universidad de Extremadura, Cáceres.

PANDER, C.H. 1830. Beiträge zur Geognosie des Russichen Reiches. 165 pp. Gedruckt bei K. Kray, St. Petersburg.

Pärnaste, H. 2008. Xylabion and related genera, 307-312. In Rábano, I., Gozalo, R. \& García-Bellido, D. (eds) Advances in trilobite research. Cuadernos del Museo Geominero 9.

PašKeVIČIUS, J. 1994. Baltijos Respublikř Geologija [The Geology of the Baltic Republics]. 447 pp. Vastybinis leidybos centras, Vilnius.

Percival, I.G. 2009. Late Ordovician Strophomenide and Pentameride Brachiopods from central New South Wales. Proceedings of the Linnean Society of New South Wales 130, 157-178.

Pereira, S., Silva, C.M. da, Pires, M. \& SÁ, A.A. 2015a. The oldest brachymetopid trilobite record from the European peri-Gondwana. Bulletin of Geosciences 90(3), 543-553. DOI 10.3140/bull.geosci.1535

Pereira, S., Sá, A., Pires, M. \& Silva, C.M. da 2015 b. Biostratigraphical review and palaeobiogeographical remarks on the trilobite genus Lichas Dalman, 1827. The Palaeontological Association 59 $9^{\text {th }}$ Annual Meeting 2015, Programmes and Abstracts, 36.

Pickerill, R.K. \& Brenchley, P.J. 1979. Caradoc marine communities of the south Berwyn Hills, North Wales. Palaeontology 22, 229-264.

Popov, L.E., Cocks, L.R.M. \& Nikitin, I.F. 2002. Upper Ordovician brachiopods from the Anderken Formation, Kazakhstan: their ecology and systematics. Bulletin of the British Museum (Natural History), Geology 58, 13-79.

ReED, F.R.C. 1917. The Ordovician and Silurian Brachiopoda of the Girvan district. Transactions of the Royal Society of Edinburgh 51(4), 795-998. DOI 10.1017/S0080456800011959

RicKardS, R.B. 2002. The graptolitic age of the type Ashgill Series (Ordovician), Cumbria, UK. Proceedings of the Yorkshire Geological Society 54, 1-16. DOI 10.1144/pygs.54.1.1

RICKARDS, R.B. 2004. The significance of the graptoloid Amphigraptus divergens from the (mid-Rawtheyan) type section of the Ashgill Series, Ordovician. Geological Magazine 141, 735-738. DOI 10.1017/S0016756804009938

RoBARDET, M. 1976. L'originalite du segment hercynien sudiberique au Paleozoique inferieur: Ordovicien, Silurien et Devonien dans le nord de la Province de Seville (Espagne). Comptes rendues des seances de l'Academie des Sciences Paris (D) 283, 999-1002.

Rong, J.Y. \& HaRPER, D.A.T. 1988. A global synthesis of the 
latest Ordovician Hirnantian brachiopod faunas. Transactions of the Royal Society of Edinburgh: Earth Sciences 79, 383-402. DOI 10.1017/S026359330001436X

RonG, J.Y. \& ZHAN, R.B. 1996. Distribution and ecological evolution of the Foliomena fauna (Late Ordovician brachiopods), 90-97. In WANG, H.Z. \& WANG, X.L. (eds) Centennial Memorial Volume of Prof. Sun Yunzhu: Palaeontology and Stratigraphy. China University of Geosciences Press, Beijing.

Rong, J.Y., Zhan, R.B. \& HARPER, D.A.T. 1999. Late Ordovician (Caradoc-Ashgill) Brachiopod Faunas with Foliomena Based on Data from China. Palaios 14, 412-431. DOI 10.2307/3515394

Sá, A.A., Piçarra, J., Vaz, N., Sequeira, A. \& GutiérrezMARCO, J.C. 2011. Ordovician of Portugal. In $11^{\text {th }}$ International Symposium on the Ordovician System, Pre-Conference Field Trip Guide. 79 pp.Universidade de Trás-os-Montes e Alto Douro-CSIC-Museo Geominero, Alcalá de Henares.

SAYAR, C. \& Cocks, L.R.M. 2013. A new Late Ordovician Hirnantia brachiopod Fauna from NW Turkey, its biostratigraphical relationships and palaeogeographical setting. Geological Magazine 150, 479-496.

DOI 10.1017/S0016756812000520

Schmid, F. 1894. Revision der Ostbaltischen Silurischen Trilobiten. Abt. 4. Calymmeniden, Proetiden, Bronteiden, Harpediden, Trinucleiden, Remopleuriden und Agnostiden. Memoires de l'Académie Impériale des sciences de St. Pétersbourg 42(5), 1-93.

Schuchert, C. \& Cooper, G.A. 1931. Synopsis of the Brachiopod genera of the suborders Orthoidea and Pentameroidea, with notes on the Telotremata. American Journal of Science 22, 241-251. DOI 10.2475/ajs.s5-22.129.241

ŠNAJDR, M. 1982. New trilobites from the Bohdalec Formation (Berounian) in the Barrandian. Věstník Ústředního ústavu geologického 57(4), 227-230.

SouZA-BRANDÃo, V. 1910. Contribuições para a petrographia de Portugal. Descrição de algumas rochas da região de Penacova. Communicaçoes da Secção dos Trabalhos Geológicos de Portugal 8, 110-142.

Sowerby, J. DE C. 1839. Fossil shells of the lower Ludlow age. In Murchinson, R.I. (ed.) The Silurian System, founded on geological researches in the counties of Salop, Hereford, Radnor, Montgomery, Caermarthen, Brecon, Pembroke, Monmouth, Gloucester, Worcester, and Stafford; with descriptions of the coalfields and overlying formations. $735 \mathrm{pp}$. John Murray, London.

S̆ToRCH, P. 1990. Upper Ordovician-lower Silurian sequences in the Bohemian Massif, central Europe. Geological Magazine 127, 225-239. DOI 10.1017/S0016756800014503

Štorch, P. \& Mergl, M. 1989. Králodvor/Kosov boundary and the late Ordovician environmental changes in the Prague Basin (Barrandian area, Bohemia). Sborník geologických věd, Geologie 44, 117-153.

TÖRNQUIST, S.L. 1884. Undersökningar öfver Siljansområdets trilobitfauna. Sveriges Geologiska Undersökning C66, $1-101$.
VANĚK, J. \& VALÍČEK, J. 2001. New index of the genera, subgenera, and species of Barrandian trilobites. Part A-B (Cambrian and Ordovician). Palaeontologia Bohemiae 7, 1-49.

VANĚK, J. \& VOKÁČ, V. 1997. Trilobites of the Bohdalec Formation (Upper Berounian, Ordovician, Prague Basin, Czech Republic). Palaeontologia Bohemiae 3, 20-50.

VILlas, E. 1985. Braquiópodos del Ordovícico medio y superior de las Cadenas Ibéricas Orientales. Memorias del Museo Paleontológico de la Universidad de Zaragoza 1, 1-153.

ViLLAs, E. 1995. Caradoc through early Ashgill brachiopods from the Central-Iberian Zone (Central Spain). Geobios 28, 49-84. DOI 10.1016/S0016-6995(95)80204-5

Villas, E., Colmenar, J., Gutiérrez-Marco, J.C., GarcíaBellido, D.C., Lorenzo, S., Pereira, S. \& Álvaro, J.J. 2016. The Hirnantia fauna and the stratigraphic assessment of the uppermost Ordovician in the central Anti-Atlas (Morocco). $35^{\text {th }}$ International Geological Congress, 4958. https://www.americangeosciences.org/igc/16439

Villas, E., Hammann, W. \& Harper, D.A.T. 2002a. Foliomena fauna (Brachiopoda) from the Upper Ordovician of Sardinia. Palaeontology 4, 267-295. DOI 10.1111/1475-4983.00237

Villas, E., Vennin, E., Álvaro, J.J., Hammann, W., Herrera, Z.A. \& Piovano, E.L. 2002b. The late Ordovician carbonate sedimentation as a major triggering factor of the Hirnantian glaciation. Bulletin de la Societé Géologique et Minéralogique de Bretagne (C) 173, 569-578. DOI 10.2113/173.6.569

Vinassa de Regny, P. 1927. Fossili Ordoviciani sardi. Memorie della reale Accademia dei Lincei 2, 437-496.

VINN, O. 2005. The distribution of worm borings in brachiopod shells from the Caradoc Oil Shale of Estonia. Carnets de Géologie/Notebooks on Geology - Article 2005/03. http://paleopolis.rediris.es/cg/CG2005_A03/

Williams, A. 1962. The Barr and Lower Ardmillan Series (Caradoc) of the Girvan District, south west Ayrshire, with description of the Brachiopoda. Geological Society London, Memoirs 3, 1-267.

Williams, A. 1963. The Caradocian brachiopod faunas of the Bala District, Merionethshire. Bulletin of the British Museum (Natural History), Geology 8, 327-471.

Wright, A.D. 1964. The fauna of the Portrane Limestone, II. Bulletin of the British Museum (Natural History), Geology 9, $157-256$.

Young, T.P. 1985. The stratigraphy of the Upper Ordovician of central Portugal. 441 pp. Ph.D. thesis, University of Sheffield, Sheffield, United Kingdom.

YounG, T.P. 1988. The lithostratigraphy of the upper Ordovician of central Portugal. Journal of the Geological Society 145, 377-392. DOI 10.1144/gsjgs.145.3.0377

Zalasiewicz, J. A., Taylor, L., Rushton, A.W.A., Loydell, D. K., Rickards, R.B. \& Williams, M. 2009. Graptolites in British stratigraphy. Geological Magazine 146, 785-850. DOI 10.1017/S0016756809990434

Zamora, S., Colmenar, J. \& Ausich, W.I. 2014a. The echinoderm faunas from the Fombuena Formation (Upper Ordovician, Iberian Chains, Spain). XXX Jornadas de la 
Sociedad Espańola de Paleontología. Fundamental! 24, $257-$ 259.

Zamora, S., Colmenar, J., Deline, B., Sheffield, S.L. \& SumRALL, C.D. 2014b. New data on Late Ordovician (Katian) echinoderms from Sardinia, Italy. Geological Society of America Abstracts with Programs 46(6), 139.

Zноu, Z.Y. \& Zноu, Z.Q. 2008. Chapter 8. Latest Cambrian and
Ordovician, 208-274. In ZHou, Z.Y.\& ZHEN, Y.Y. (eds) Trilobite Record of China. Science Press, Beijing.

Zhou, Z., YuAN, W. \& Zhou, Z. 2010. Evolutional trends and palaeobiogeography of the Ordovician trilobite Ovalocephalus Koroleva 1959. Proceedings of the Royal Society of London B: Biological Sciences 277(1679), 257-266. 